\title{
Prominent Human Health Impacts from Several Marine Microbes: History, Ecology, and Public Health Implications
}

\author{
P. K. Bienfang, ${ }^{1}$ S. V. DeFelice, ${ }^{1}$ E. A. Laws, ${ }^{1}$ L. E. Brand, ${ }^{2}$ R. R. Bidigare, ${ }^{1}$ \\ S. Christensen, ${ }^{1}$ H. Trapido-Rosenthal, ${ }^{1}$ T. K. Hemscheidt, ${ }^{1}$ D. J. McGillicuddy Jr., ${ }^{3}$ \\ D. M. Anderson, ${ }^{3}$ H. M. Solo-Gabriele, ${ }^{4}$ A. B. Boehm, ${ }^{5}$ and L. C. Backer ${ }^{6}$ \\ ${ }^{1}$ Center for Oceans and Human Health, Pacific Research Center for Marine Biomedicine, \\ School of Ocean and Earth Science and Technology, MSB no. 205, University of Hawaii, Honolulu, HI, 96822, USA \\ ${ }^{2}$ Rosenstiel School of Marine and Atmospheric Science, University of Miami, 4600 Rickenbacker Cswy, Miami, FL 33149, USA \\ ${ }^{3}$ Woods Hole Oceanographic Institution, Woods Hole, MA 02543, USA \\ ${ }^{4}$ Department of Civil, Architectural, and Environmental Engineering, University of Miami, Coral Gables, \\ Florida and University of Miami Center for Oceans and Human Health, Key Biscayne, FL 33124-0630, USA \\ ${ }^{5}$ Department of Civil and Environmental Engineering, Stanford University, Stanford, California and \\ University of Hawaii Center for Oceans and Human Health, Honolulu, HI 96822, USA \\ ${ }^{6}$ National Center for Environmental Health Centers for Disease Control and Prevention, \\ 47770 Buford Highway NE MS F-46, Chamblee, GA 30341, USA
}

Correspondence should be addressed to P. K. Bienfang, bienfang@soest.hawaii.edu

Received 15 June 2010; Revised 23 July 2010; Accepted 25 July 2010

Academic Editor: Max Teplitski

Copyright (C) 2011 P. K. Bienfang et al. This is an open access article distributed under the Creative Commons Attribution License, which permits unrestricted use, distribution, and reproduction in any medium, provided the original work is properly cited.

\begin{abstract}
This paper overviews several examples of important public health impacts by marine microbes and directs readers to the extensive literature germane to these maladies. These examples include three types of dinoflagellates (Gambierdiscus spp., Karenia brevis, and Alexandrium fundyense), BMAA-producing cyanobacteria, and infectious microbes. The dinoflagellates are responsible for ciguatera fish poisoning, neurotoxic shellfish poisoning, and paralytic shellfish poisoning, respectively, that have plagued coastal populations over time. Research interest on the potential for marine cyanobacteria to contribute BMAA into human food supplies has been derived by BMAA's discovery in cycad seeds and subsequent implication as the putative cause of amyotrophic lateral sclerosis/parkinsonism dementia complex among the Chamorro people of Guam. Recent UPLC/MS analyses indicate that recent reports that BMAA is prolifically distributed among marine cyanobacteria at high concentrations may be due to analyte misidentification in the analytical protocols being applied for BMAA. Common infectious microbes (including enterovirus, norovirus, Salmonella, Campylobacter, Shigella, Staphylococcus aureus, Cryptosporidium, and Giardia) cause gastrointestinal and skin-related illness. These microbes can be introduced from external human and animal sources, or they can be indigenous to the marine environment.
\end{abstract}

\section{Introduction}

The health and welfare of humans residing in the coastal zone and in island communities are inextricably linked to the oceans and its foodwebs. The multitude of relationships between human societies and the oceans has led to many human dimensions of ocean issues and processes. The effects of climate change, pollution, population increases, and the myriad of anthropogenic effects attendant increasing population are all related in various ways to the microbial organisms that are at the base of marine ecosystems. In 2004, the National Science Foundation and the National Institutes of Environmental Health Sciences initiated collaborative funding of four centers for oceans and human health, and in the same year, the National Oceanic and Atmospheric Administration launched its Oceans and Human Health Initiative. One of the important accomplishments of these centers has been the cross-discipline synergistic collaboration of scientists within and between centers. This paper summarizes five 
areas of this research focusing on the oceans and human health.

\section{Gambierdiscus spp. and Ciguatera Fish Poisoning}

Gambierdiscus spp., a genus of dinoflagellates (division Phyrophyta), produce natural toxins that cause ciguatera fish poisoning (CFP) in humans. In contrast to other noxious dinoflagellates known for their dense "red tide" aggregations, Gambierdiscus do not form conspicuous blooms that color the water. These dinoflagellates normally grow epiphytically on various macroalgae in coral reef ecosystems within the $35^{\circ} \mathrm{N}-35^{\circ} \mathrm{S}$ latitudinal band. The dinoflagellates are consumed by herbivorous fish, beginning processes of bioaccumulation and biomodification through the reef food web, as the herbivores are consumed by carnivores and ultimately by humans. Several informative reviews on CFP may be found in Bienfang et al. [1], Dickey [2], and Dickey and Plakas [3] and references cited therein.

Ciguatera is a food-borne disease that has affected coastal populations and travelers in tropical and subtropical regions throughout the world for centuries. Ship logs as far back as the 16th century mention clinical symptomologies consistent with CFP $[4,5]$, and during WWII, CFP was a serious problem for military troops stationed in many Pacific island locals. There are at least 50,000 reported cases of CFP cases per year $[6,7]$, but due to the high degree of misdiagnosis and underreporting, it is estimated that the actual frequency of CFP cases is closer to 500,000 per year $[8,9]$. It is estimated that $>50 \%$ of the populations of small islands in the Caribbean and South Pacific have suffered from CFP; see reviews by Lewis [10], Lange [11], and Fleming et al. $[12,13]$.

Ciguatoxin produces gastrointestinal, neurological, and cardiovascular symptoms. These normally develop within 12-24 hours of eating contaminated fish. Gastrointestinal effects may disappear in four days. The normal progression of symptoms is gastrointestinal symptoms (e.g., diarrhea, abdominal pain, nausea, and vomiting), followed by neurological symptoms (e.g., numbness and tingling of hands and feet, dizziness, altered hot/cold perception, muscle aches, low heart rates, and low blood pressure). Symptoms may persist in some forms for weeks, months, or even years $[9,14-16]$. Generally, feelings of weakness last $\sim 1$ week, and neurosensory manifestations (e.g., muscle aches, tingling extremities, and thermal reversals) commonly represent the most prolonged discomfort. The key pathonuemonic symptom is the neurological malady of reversal of hot/cold sensation. Fortunately, death is rare (i.e., $<0.1 \%$ ) and is most commonly the result of respiratory failure due to cardiovascular shock induced by severe dehydration. An interesting feature is that CFP intoxication does not confer any immunity in its victims, and to the contrary, its frequency results in heightened sensitivity to ciguatoxin.

The etiology of CFP was advanced when work in the Gambier Islands of French Polynesia by Yasumoto et al. [17-19] revealed that the guts of toxic (herbivorous) fish contained significant numbers of a dinoflagellate that was designated as a new genus and species known as Gambierdiscus toxicus [20]. Since then several new species have been added to the genus [21-23], and recent works using refined morphological and molecular sequencing techniques have caused substantial changes to the taxonomy of this genus $[24,25]$. Derived from gambiertoxins produced by the dinoflagellates, ciguatoxin is a polar, lipid-soluble polyether. The toxin is heat stable, tasteless, odorless, and effective at extremely low (i.e., sub-ppb) concentrations; the severe analytical challenges presented by these properties have been central to the slow progress in detection of ciguatoxin for prevention and/or research purposes.

A CDC report for a period in the 70's indicted that reported CFP incidences accounted for 25\% of all foodborne outbreaks, which was five times the reported incidence for paralytic shellfish poisoning and neurological shellfish poisoning combined [26]. Kite-Powell [27] concluded that the economic impact from CFP exceeded that from any other form of hazardous algae bloom. Additionally, CFP is associated with societal/public health impacts in island communities due to dietary changes in response to concerns over the quality of local seafood. Chateau-Degat et al. [28] showed correlations of Gambierdiscus abundance and CFP with sea surface temperature in the South Pacific. This has attracted particular concern because warming oceans would expand the range of Gambierdiscus into higher latitudes where population density is generally greater. Though potentially influenced by improved awareness, the recognition of CFP in new geographic areas [29-31] has been suggested as evidence of an expanded range for CFP. Because of the underreporting artifact, it is difficult to ascertain whether CFP incidence is increasing over time, though expansion of international trade in seafood from tropical regions and climatic warming make this a distinct probability.

\section{Karenia brevis and Neurotoxic Shellfish Poisoning}

Karenia brevis is an unarmored photosynthetic dinoflagellate that lives primarily in the Gulf of Mexico and produces a suite of neurotoxins called "brevetoxins". When K. brevis occurs at concentrations above $\sim 100,000$ cells/L, humans become aware of its presence of primarily as a result of three effects. At such concentrations, brevetoxins can cause: (1) fish kills, (2) filter-feeding shellfish to become extremely toxic to humans, and (3) respiratory distress, coughing, and eye irritation in humans due to aerosolization. Such impacts were experienced long before $K$. brevis was known to be the causative agent. Spanish explorers as early as the 15 th century recorded fish kills in the Gulf of Mexico that were probably caused by K. brevis. Explorers also noticed that the native Americans were aware that shellfish could be toxic [32-34]. Davis [34] was the first to demonstrate that K. brevis was in fact the causative organism of fish kills and toxic shellfish. When first identified, it was named Gymnodinium breve. It was later renamed Ptychodiscus brevis and is currently known as Karenia brevis. 
K. brevis is an unarmored dinoflagellate with a flattened shape, approximately 10-15 microns thick and 25-35 microns in diameter. It tends to swim up to the light during the day and disperse throughout the water column at night $[35,36]$. It typically reproduces by binary fission every $2-5$ days [37]. It is suspected to have a resting stage, perhaps in the benthos, but this is not firmly established at the present time [38].

Under typical nonbloom conditions, $K$. brevis concentrations are usually $<10$ cells/L offshore and $\sim 1000$ cells $/ \mathrm{L}$ inshore [39]. For reasons that are still not well understood, it occasionally forms blooms with concentrations of one to tens millions of cells per liter. K. brevis has been observed sporadically throughout the Gulf of Mexico, but the largest and most frequent blooms occur along the west coast of Florida $[32,33,40]$. Although not as frequent, blooms also occur along the coast of Texas and Mexico [32]. About once a decade, conditions allow the Loop Current in the Gulf of Mexico to pick up blooms of K. brevis and transport it through the Straits of Florida and along the east coast of North America $[32,41]$. As a result, blooms of $K$. brevis have been found as far north as North Carolina [41]. Currently, there is no evidence that these blooms along the east coast were generated locally, but rather were transported there from the Gulf of Mexico.

Along the west coast of Florida, where records have been kept for a half century, blooms of $K$. brevis are statistically more likely during the fall months, a month or two after the heaviest freshwater runoff from land [40] although they can occur at any time of the year. Huge year-to-year variations in bloom concentrations and/or duration are evident. In some years, essentially no blooms are observed, some years have short sporadic blooms, and some years large blooms may persist throughout the entire year.

Understanding the causes for the spatial and temporal occurrence/variability of $\mathrm{K}$. brevis blooms is an area of active research. Factors that promote initiation of blooms may well be different from those that determine its extent and/or duration. Physical aggregation due the interaction of complex hydrography and the swimming behavior of $K$. brevis is probably also important. Olascoaga et al. [42] have argued that areas of low mixing due to certain hydrographic features along the west coast of Florida allow the slow growing $K$. brevis to accumulate large populations without being dispersed by mixing and dilution rates larger than its growth rate.

A variety of hypotheses have been proposed for the sources of nutrients that would ultimately influence the concentrations and spatial extent of K. brevis blooms. Gunter et al. [43], Rounsefell and Nelson [44], Dixon and Steidinger [45], and Brand and Compton [40] have argued that nutrients in land runoff could be an important source. Lenes et al. [46], Walsh and Steidinger [47], and Walsh et al. [48] have argued that iron-rich atmospheric dust stimulation of nitrogen-fixing Trichodesmium in phosphorus-rich waters is an important nutrient source that can stimulate blooms of K. brevis. Hu et al. [49] have argued that nutrient-rich groundwater could be important. Vargo et al. [50] have argued that, along with other sources, fish that have died in blooms of $K$. brevis could be an important source of nutrients as they decompose. A perusal of the data on the spatial and temporal distribution of $K$. brevis blooms suggests that no one hypothesis will provide a simple explanation for its distribution. A variety of nutrient sources probably contribute to varying degrees to blooms of $K$. brevis.

$K$. brevis produces a suite of around 12 brevetoxins that activate the sodium channel of neurons [51]. At concentrations $>100,0000$ cells/L, blooms of K. brevis can kill many marine animals, including fish, turtles, sea birds, manatees, and dolphins [52]. Because brevetoxins are large lipidsoluble molecules, they tend to accumulate in fatty tissues and are not easily broken down or excreted. As a result, filterfeeding shellfish can accumulate high concentrations in their tissues. Brevetoxins are heat and acid stable, thus remain toxic after cooking. Human ingestion of toxic shellfish can lead to a variety of neurological and gastrointestinal symptoms [53], giving the general term "neurotoxic shellfish poisoning" (NSP). Because of this, government agencies in Florida monitor for K. brevis blooms and close shellfish beds to harvesting at times of blooms [53]. As a result, NSP is now rare, usually the result of illegal or uninformed harvesting of toxic shellfish.

Because the brevetoxins are lipid soluble, they also have the potential to accumulate and biomagnify up the food chain [54]. As a result, sublethal concentrations of $K$. brevis can still have lethal consequences [40]. Sublethal concentrations of $K$. brevis that do not kill nevertheless release brevetoxins that accumulate in organisms; thus higher level predators can accumulate high concentrations in their tissues. This may explain why dolphins and manatees have been found dead with high concentrations of brevetoxin in their stomachs and tissues in areas where no obvious blooms of K. brevis were observed [55]. Naar et al. [56] have found brevetoxins in the tissues of many fish species many months after the occurrence of a K. brevis bloom. These recent data suggest that brevetoxins may be more widespread in seafood than previously thought.

As an unarmored dinoflagellate, $K$. brevis is delicate compared to most toxic dinoflagellate species. As a result, cells can be broken apart by turbulence due to wave action at the sea surface and along beaches. This results in aerosolization of brevetoxins that may be inhaled by humans and resulting in respiratory distress, coughing, and eye irritation in humans [57-60]. Hospital emergency room admittances for respiratory distress increase 50\% when blooms of $K$. brevis occur [61] and is particularly acute in people with asthma $[59,62]$. Beaches along the west coast of Florida are major recreational areas for Florida residents, including many elderly retirees and tourists. When large blooms of K. brevis develop, dead fish wash up on the beaches and/or brevetoxin aerosolization occurs and the tourism suffers considerable economic loss [63].

\section{BMAA-Containing Cyanobacteria}

Cyanobacteria have been a part of the human diet primarily in non-Western civilizations for centuries. Today, 
cyanobacteria are produced in mass, controlled cultivation processes and/or harvested from natural habitats and marketed as food supplements around the world. Historical and current uses of cyanobacteria and their derivative products are thoroughly reviewed by [64]. The amino acid $\beta-\mathrm{N}$ methylamino-L-alanine (BMAA) is one of a number of biologically active natural compounds produced by cyanobacteria, and its potential importance in species of marine cyanobacteria has attracted considerable research attention recently.

BMAA was originally discovered in cycad seeds [67], and later implicated the etiology of Amyotrophic Lateral Sclerosis/Parkinsonism Dementia Complex (ALS/PDC) that occurs among the Chamorro people of Guam [68]; see TemaNord [69] for an exhaustive review on this subject. BMAA is biomagnified in the Guam ecosystem and occurs in the brain tissues of Chamorros who died of ALS/PDC [70]. Axenic cultures of the endosymbiont cyanobacterium, Nostoc sp., isolated from the coralloid roots of the cycad palm, Cycas micronesica Hill, produce free BMAA at a concentration of $0.3 \mu \mathrm{g} g^{-1}$. Following up on this work, Cox et al. [71] examined BMAA production in freeliving and symbiotic clones representing the five morphotypes of cyanobacteria (cf. Rippka et al. [72].) A wide range of cyanobacterial strains were screened, including strains maintained at the University of Dundee in Scotland, Stockholm University in Sweden, and the University of Hawaii in the United States. Liquid chromatographymass spectrometry (LC/MS) and high-performance liquid chromatography (HPLC) were employed to identify and quantify free and protein-associated BMAA for each sample. For free-living cyanobacteria, Cox et al. [71] found that BMAA was produced by members of all five cyanobacterial morphotypes as well as $95 \%$ of the genera and $97 \%$ of the strains that were screened. Analysis of Nostoc strains isolated from symbiotic relationships with fungi and host plants of broad taxonomic diversity indicated that $73 \%$ of these strains produced BMAA. The ubiquity of cyanobacteria in diverse terrestrial and aquatic environments suggests that ingestion of BMAA may occur through even less esoteric routes, including direct consumption of cyanobacteria or cyanobacterial hosts, bioaccumulation in additional food chains, or exposure to cyanobacteria-contaminated water supplies. Cox et al. [71] recommended that BMAA concentrations should be monitored in invertebrates, fish, and/or grazing animals used for human consumption that either directly consume cyanobacteria or forage on plants or prey that may have accumulated cyanobacteria-produced BMAA. This conclusion was reinforced by subsequent articles published in the Journal of the American Medical Association $[73,74]$ and Neuropathology and Applied Neurobiology [75].

The amino acid, $\beta$-N-methylamino-L-alanine (BMAA), is an excitotoxic neurotoxin that functions as a glutamate agonist. By virtue of its unique structural characteristics, BMMA reacts with $\mathrm{CO}_{2}$ at physiological $\mathrm{pH}$ to form $\alpha$ - and $\beta$-carbamate adducts $[65,66,76]$ that are structurally similar to the neurotransmitter glutamate and its selective agonist N-methyl-d-aspartate (NMDA) (Figure 1).
Rao et al. [77] have demonstrated that in the presence of $5 \% \mathrm{CO}_{2}$, BMAA causes selective motor neuron loss in dissociated mixed spinal cord cultures at concentrations of $\sim 30 \mu \mathrm{M}$. These investigators also reported that the glutamate receptor antagonist 2,3-Dioxo-6-nitro-1,2,3,4tetrahydrobenzo[f] quinoxaline-7-sulfonamide (NBQX) prevented BMAA-induced death, implicating BMAA in the excitotoxic activation of receptors for $\alpha$-amino-3-hydroxy-5methyl-4-isoxazolepropionic acid (AMPA) and kainic acid, and that BMAA selectively induced the production of reactive oxygen species (ROS) in motor neurons. More recently, Lobner et al. [78] demonstrated that BMAA also functions as an agonist for the NMDA and mGluR5 receptors in mouse cortical cell cultures. In addition to AMPA/kainate, NMDA and mGluR5 receptor activation and oxidative stress, BMAA may also induce toxicity by inhibiting the reuptake of glutamate. Furthermore, BMAA may be misidentified by transfer RNAs, resulting in its misincorporation into proteins.

Since the initial report of the widespread distribution of BMAA in representatives of all five cyanobacteria morphotypes by Cox et al. [71], there have been a number of conflicting studies published regarding the detection and quantification of BMAA in cyanobacteria (including blue green algae nutritional supplements). Eleven studies have confirmed the presence of BMAA in a wide range of marine, brackish, and freshwater cyanobacteria via LC/MS, LC/MS/MS or GC/MS methods that identify and detect underivatized $[79,80]$ and derivatized $[75,81-88]$ BMAA. By comparison, four studies were not able to detect the presence of BMAA in a wide range of cyanobacteria via HPLC, LC/MS, or LC/MS/MS that identify and detect derivatized [89] and underivatized BMAA [90-92]. These disparate findings are likely caused by analyte misidentification [91, 92] and/or differences in methodological sensitivities [88]. Because of potential coelution artifacts, we recommend that that BMAA identification and quantification be based on the LC/MS analysis of BMAA-specific fragments $(\mathrm{m} / \mathrm{z}$ 88) [91] or AQC-derivatized BMAA $(m / z$ 258) [88] in order to minimize the possibility of reporting false positive data $[88,91]$. Based on this criterion, only four studies at the time of this writing have confirmed the presence of BMAA in cyanobacteria $[79,80,87,88]$. Due to the serious implications of BMAA and neurodegenerative disease, it is further recommended that NMR analysis be used for the unequivocal identification of BMAA in biological samples. It should be noted that two studies employing LC/MS analysis of BMAA-specific fragments failed to detect BMAA in a wide range of cyanobacteria samples [91, 92]. We conclude that BMAA was either absent or below the limit of detection in these samples. Spáčil et al. [88] recommend subjecting samples to a pretreatment protocol to both remove impurities and to concentrate BMAA prior to LC/MS analysis. Finally, we recommend that future studies should monitor BMAA concentrations using only BMAA-specific LC/MS methods in animals used for human consumption that either directly consume cyanobacteria or forage on plants or prey that may have accumulated cyanobacteriaproduced BMAA. 


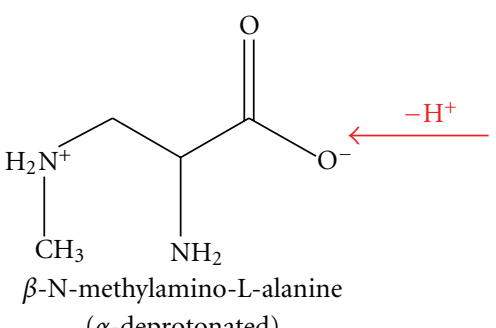

$(\alpha$-deprotonated)<smiles>C[NH2+]CC(NC(=O)O[O-])C(=O)[O-]</smiles>

$\alpha$-N-carboxy- $\beta$-methylamino-L-alanine

(BMAA- $\alpha-\mathrm{NCO}_{2}$ )

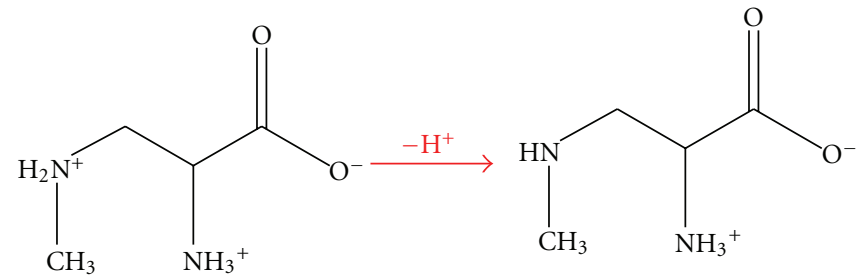

$\beta$-N-methylamino-L-alanine (L-BMAA)
$\beta$-N-methylamino-L-alanine ( $\beta$-deprotonated)

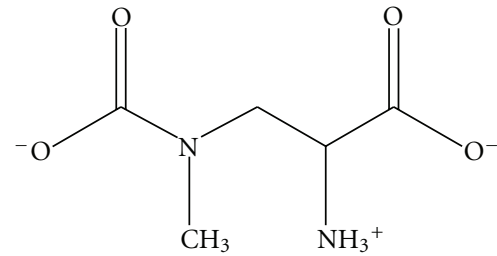

$\beta$-(N-carboxy-N-methyl)-amino-L-alanine (BMAA- $\beta-\mathrm{NCO}_{2}$ )

Figure 1: Reaction of the $\alpha$ - and $\beta$-amino groups of BMAA with $\mathrm{CO}_{2}$ to form the corresponding carbamate adducts (after [65, 66]).

\section{Alexandrium fundyense and Paralytic Shellfish Poisoning}

Paralytic shellfish poisoning (PSP) has been recognized in the Pacific Northwest of the United States for centuries [93]. Human poisonings have been recorded primarily in North America, Asia, and Europe [94], but outbreaks have been reported worldwide $[93,95,96]$. PSP is caused by eating bivalve shellfish (clams, mussels, scallops, etc.) contaminated with one or more of a group of structurally related congeners of saxitoxin [97]. Filter-feeding fish can sometimes be vectors for the toxins as well.

Saxitoxins are produced by dinoflagellates of the genera Gymnodinium [101], Alexandrium [95, 96], and Pyrodinium $[97,101]$. These toxins act to selectively block the voltagegated sodium channel of excitable membranes, thus blocking the generation and propagation of action potentials in nerve axons and skeletal muscle fibers. Mammals, birds, and fish can be affected by PSP toxins; however, humans are the most sensitive-the fatal oral dose of saxitoxin is 1-4 mg [102].

PSP symptoms begin to occur within 30 minutes to three hours of eating contaminated seafood. The initial symptoms include paresthesia and numbness around the lips and mouth [93]. These sensations then spread to the face and neck. Victims may also experience nausea and vomiting. In moderately severe poisonings, paresthesia progresses to the arms and legs. Victims may experience giddiness, incoherent speech, and light-headedness. In severe poisonings, death can result from respiratory failure and hypoxia. Historically, the fatality rate from PSP varies from no deaths in recent outbreaks in the U.S. or Europe to rates of $2 \%-14 \%$ in other parts of the world [93]. The frequency of mortalities is related to the availability of emergency hospital care, past experience with PSP outbreaks, and whether or not effective monitoring programs are in place to prevent contaminated shellfish from entering commercial markets. However, despite warning signs and other outreach efforts, recreational harvesters still become victims of PSP. For example, in June 2010, five cases of suspected PSP, including two fatalities, were reported in Anchorage Daily News due to shellfish collected from waters in Alaska, US. The victims had eaten personally harvested shellfish and crabs, including those from areas normally avoided because of historically high levels of contamination.

The causative organism in New England PSP outbreaks is Alexandrium fundyense. Although the Bay of Fundy and northeastern Canadian waters have a long history of PSP, in the U.S., toxicity was restricted to far-eastern Maine (ME) until 1972, when a massive, visible red tide of $A$. fundyense stretched from ME to Massachusetts (MA), causing toxicity in some southern areas for the first time. Virtually every year since 1972, western ME has experienced PSP outbreaks, and for the first 20 years of that interval, MA did as well. That pattern was a direct result of $A$. fundyense cysts being retained in western GOM waters after the 1972 bloom and subsequent events [103]. Between 1994 and 2004, toxicity was infrequent in MA and the southern GOM. Then in 2005, another massive bloom occurred [98], leading to closure of shellfish beds from ME to southern MA and $40,000 \mathrm{~km}^{2}$ of offshore federal waters as well. Economic losses in 2005 were estimated to be $\$ 50$ million for the MA shellfish industry alone.

A. fundyense has a complex life cycle includes a resting cyst, a phase of vegetative growth, sexual reproduction, and re-encystment (Figure 2(a)). Observations indicate several salient characteristics of the vegetative cell distributions: patterns of abundance are gulf-wide in geographic scope; 


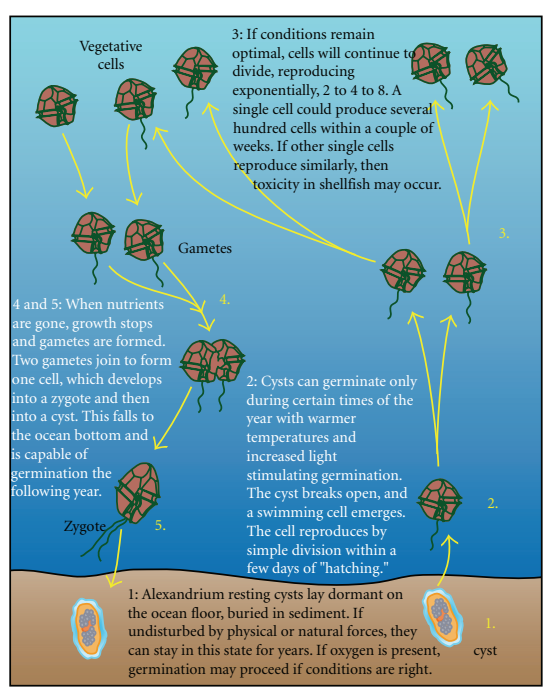

(a)

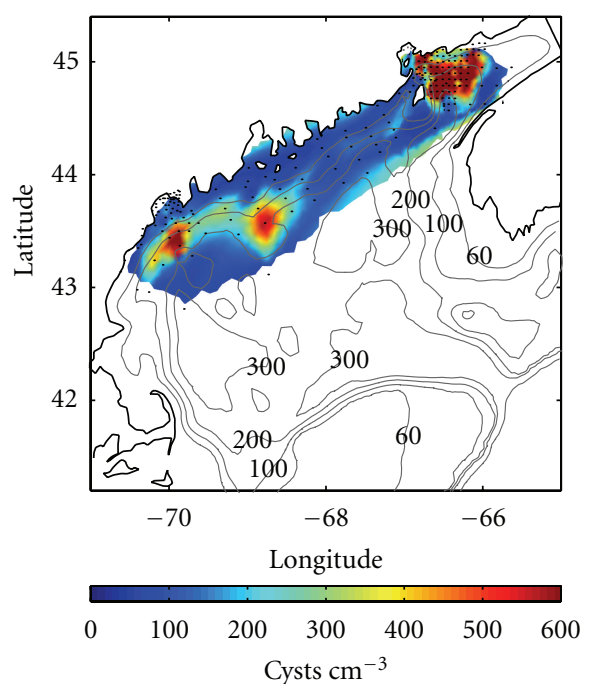

(b)

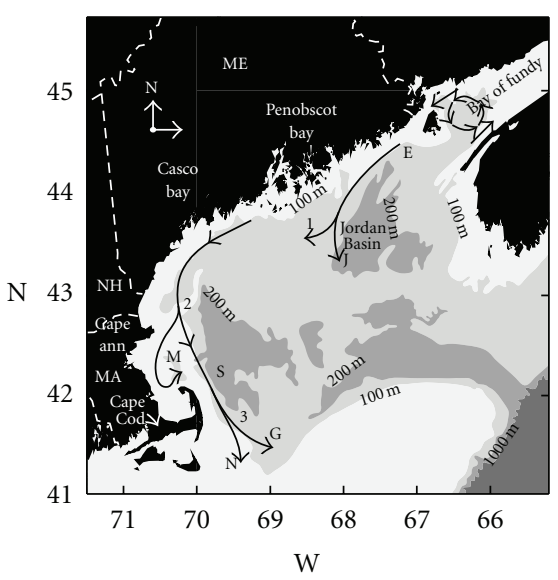

(c)
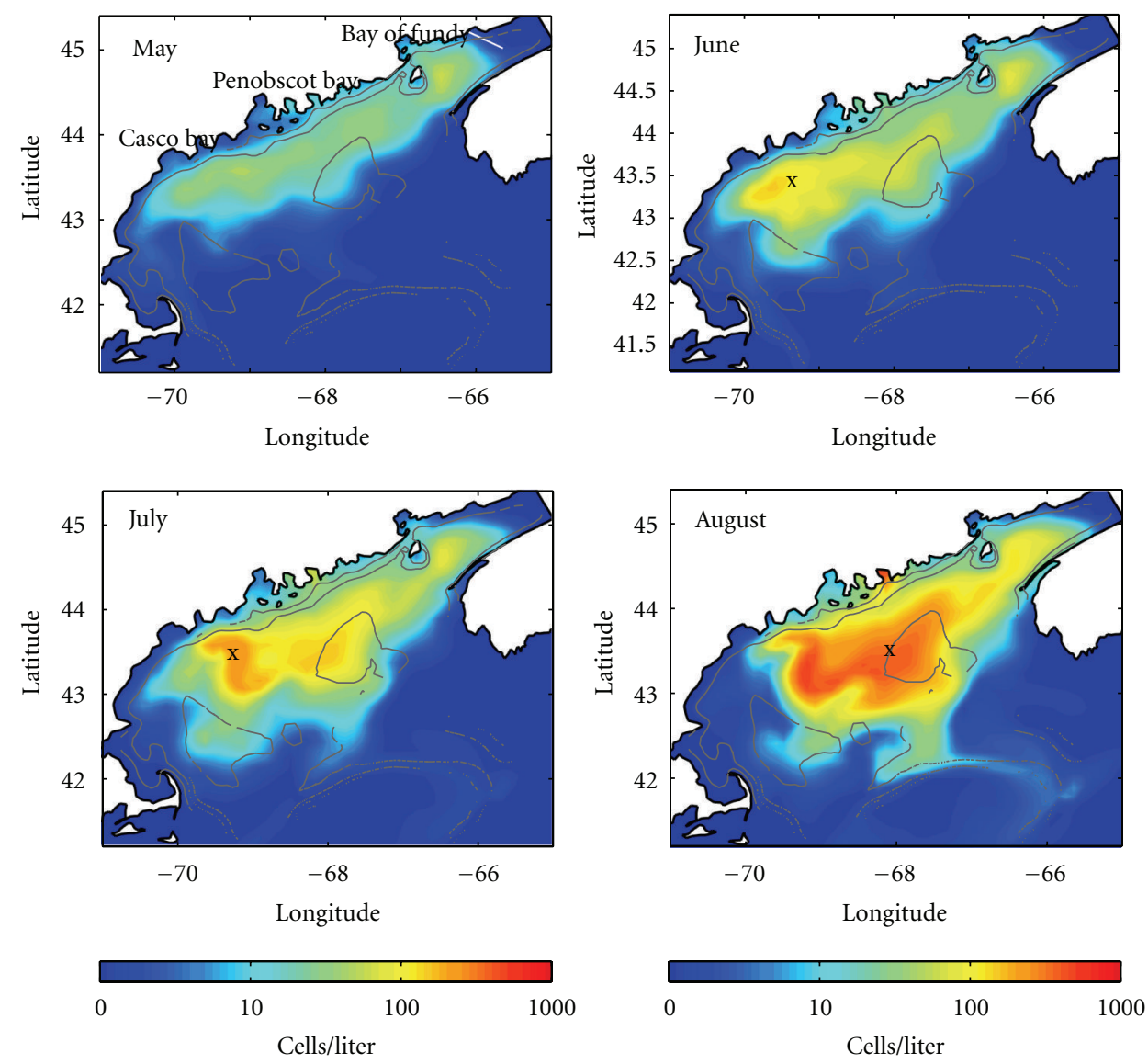

(d)

Figure 2: Upper left: life cycle of $A$. fundyense. Upper middle: distribution of cysts (number of cysts $\mathrm{cm}^{-3}$ ) in the upper $3 \mathrm{~cm}$ of sediment derived from a 1997 survey of the Gulf of Maine [98] and surveys of the Bay of Fundy in 1981 (White and Lewis, 1982), 1982, and 1983 (data provided by Jennifer Martin, DFO). Upper right: schematic of the Maine Coastal Current, reprinted from McGillicuddy et al. [99]. Branch points are located at (1) Penobscot Bay, (2) Cape Ann, and (3) Great South Channel. Seven segments of the current are indicated: (E)astern, (J)ordan, (W)estern, (M)assachusetts, (S)tellwagen, (N)antucket, and (G)eorges Bank. Dashed white lines denote state boundaries of Maine (ME), New Hampshire (NH), and Massachusetts (MA). From Backer and McGillicuddy [100]. Reprinted with permission from Oceanography. 
the distributions are associated with the Maine Coastal Current, and the center of mass of the distribution is from west to east during the April-to-August growing season [104]. This latter aspect is particularly notable given the coastal current flows in the opposite direction (Figure 2(b)). A model based on the seasonal mean flow that includes germination, growth, mortality, and nutrient limitation can produce simulations that are qualitatively consistent with the observations (Figure 2(c); [99]. In general, cells germinated from the major cyst beds in the Bay of Fundy and near Penobscot and Casco Bays (Figure 2(d)) are advected in the alongshore direction from east to west in the coastal current. Growth of the vegetative cells is limited primarily by temperature from April through June throughout the gulf whereas nutrient limitation occurs in July and August in the western gulf. Thus, the seasonal shift in the center of mass of cells from west to east can be explained by changing growth conditions: growth is more rapid in the western gulf early in the season due to warmer temperatures whereas growth is more rapid in the eastern gulf later in the season due to severe nutrient limitation in the western gulf during that time period. Hydrodynamic transport of these offshore populations to inshore shellfish beds is a key aspect regulating the PSP threat to human health $[100,105,106]$.

In the wake of the historic bloom of 2005 in the western GOM, a suite of models was used to diagnose the underlying causes. Anderson et al. [98] described three factors to explain the 2005 bloom: (1) high abundance of resting cysts in fall 2004 that provided a large inoculums, (2) storms with strong northeast winds that carried toxic cells towards and along the coast, and (3) abundant fresh water runoff, providing macro- and micronutrients, a stratified water column, and an alongshore (towards the southwest) transport mechanism. These factors were evaluated using a sensitivity analysis that utilized field observations and a model of $A$. fundyense population dynamics [99, 107, 108], coupled to a regional circulation model to hindcast the 2005 bloom [109, 110]. Initial conditions of the three sensitivity experiments are identical to the central hindcast (an animated version of the central hindcast is available at http://science.whoi.edu/users/ruoying/Redtide_05/Papers/ avg_fields.avi) in all respects except: experiment 1 utilizes the 1997 cyst map instead of 2004; experiment 2 is forced by winds from a more typical year (2004) instead of the strong downwelling-favorable winds of 2005; experiment 3 uses riverine discharge from a typical year (2004) instead of the anomalously large discharge of 2005. This sensitivity analysis suggests that high cyst abundance in the WGOM was the main cause of the 2005 bloom. Wind forcing was an important regulator, in the form of both episodic bursts of northeast winds and the downwelling-favorable mean condition, causing onshore advection of offshore populations. The anomalously high river runoff enhanced alongshore transport near the coast, but had limited impact on the gulf-wide bloom distribution.

Model initial conditions are dependent on maps of $A$. fundyense cyst abundance obtained on an annual basis. Mathematical representations of laboratory-derived germination and growth data are used with these maps to drive the inoculation and development of the bloom. At this point, it is not yet possible to model the formation and deposition of new cysts from these blooms, though work is ongoing in this direction. This is an area where our lack of knowledge is evident-the termination of blooms remains poorly understood, and in particular, the relationship between bloom size and the size of the resulting cyst seedbed is not established, nor indeed is it intuitive. For example, some of the largest regional blooms (e.g., in 2005 [98]) were followed by very low cyst abundance on a regional basis whereas more modest bloom years (e.g., 2007) led to widespread and high density cyst accumulations \{D.M. Anderson, unpub. data\}.

Modeling results to date suggest that simulations initiated from $A$. fundyense cyst distributions can capture largescale seasonal patterns in the distribution and abundance of vegetative cells. To the extent that cyst abundance is a firstorder predictor of regional bloom magnitude the following year in the WGOM (even though the converse is not true), that information can be used in a seasonal forecast of PSP on a regional basis. Near-real-time nowcasts and forecasts of harmful algal blooms (HABs) in the Gulf of Maine have been run routinely each year since 2006 (2006: http://science.whoi .edu/users/ruoying/Redtide_06/, 2007: http://omgrhe.meas .ncsu.edu/Redtide/Redtide_07/, 2008: http://omglnx3.meas .ncsu.edu/yli/08forecast/, 2009: http://omglnx3.meas.ncsu .edu/yli/09forecast/). During the bloom season, weekly updates have been made available to more than 150 managers and other officials and scientists involved with PSP outbreaks in the northeastern US. Web interfaces provide the latest model simulations, with one-week forecasts driven by meteorological predictions. At present, this kind of early warning appears to be the most practical approach to mitigating the impacts of these blooms, insofar as available direct intervention strategies are not practical by virtue of the fact that even in bloom conditions, A. fundyense is typically a small fraction of the total phytoplankton biomass.

\section{Infectious Microbes}

Waterborne infectious microbes normally include viruses, bacteria, and protozoa that can be transmitted through recreational exposure to seawater or consumption of seafood. Other groups of infectious microbes that are less commonly considered include the helminthes and yeasts. The infectious microbes differ from harmful algal species in that disease is caused by the growth of the microbes within humans. Thus, exposure to even low levels of infectious microbes can cause illness. Upon consumption, inhalation, or contact with the infectious microbe it then multiplies within the gastrointestinal system, respiratory tract, or within exposed skin resulting in human disease. Harmful algae, on the other hand, grow outside humans within external water bodies and release toxins that cause disease when the toxin-contaminated water is ingested or inhaled $[62,111]$. Typically, the numbers of infectious microbes that are needed to cause disease are low; the precise number depends upon the virulence of the particular strain of the microbe [112] and also the immune status of the infected host. Risks to humans from infectious microbes are evaluated 
by considering human exposure to seawater or seafood in addition to the concentration of infectious microbes therein. Infectious microbes in seawater can be separated into two groups, those which are introduced from outside sources and those which are indigenous, hereafter referred to as allochthonous and autochthonous, respectively [113].

Infectious microbes in coastal waters impact the health of a large number of people globally. Worldwide, up to 170 million enteric and respiratory illnesses attributed to swimming in and consuming shellfish from infectious microbes in coastal waters [114]. In the US, 20,300 recreational beach advisories were reported in 2008 due to contamination with fecal bacteria, up from 6,200 in 1999 [115]. In the US, $33 \%$ of shellfish harvesting waters are impaired by infectious microbes [116]. In southern California alone, it is estimated that 1.5 million excess enteric illnesses occur per year from swimming in waters with infectious microbes, at a cost of $\$ 50$ million per year [117]. One of the challenges of assessing the impact of infectious microbes on human health is that most illnesses associated with these infectious microbes are self-limiting, so medical advice is not always sought. In addition, identifying the etiologies of the illnesses can be challenging even in the most modern diagnostic laboratories. Most of the illnesses are also not reportable, so they are not tracked by a central agency. Yoder et al. [118] report Cryptosporidium as the most common etiology of freshwater recreational waterborne illness, and also reports Vibrio spp. as an important etiology for seawater-acquired recreational waterborne illness. A review of the epidemiology of seafoodassociated illness in the United States between 1973 and 2006 [119] identifies Vibrio parahaemolyticus as being responsible for the most seafood illnesses (35\%), norovirus and hepatitis A together responsible for the second highest number of illnesses (32\%), and Salmonella and Shigella together responsible for the third highest number of illnesses (19\%).

Introduced or allochthonous infectious microbes can come from human sewage, stormwater, feces of animals, and skin from infected humans during bathing. Allochthonous infectious microbes (from the virus, bacteria, and protozoan groups) include enterovirus, norovirus, Salmonella, Campylobacter, Shigella, Cryptosporidium, Giardia, Legionella sp. and Staphylococcus aureus. All of these microbes cause gastrointestinal disease with the exception of Legionella sp., which causes respiratory disease and $S$. aureus which causes skin disease. Transmission of helminthes via recreational contact with seawater is generally limited to developing countries and includes incidental ingestion of infective eggs or through contact with contaminated waters for forms that can penetrate skin [120]. In addition to infectious microbes from the virus, bacteria, and protozoan groups [121], coastal beach sands have also been implicated as a means of potentially transmitting pathogenic helminthes [122] and yeasts [123]. There are a number of excellent reviews on the occurrence of allochthonous infectious microbes, particularly bacteria, viruses, and protozoa, in coastal waters [124126] and in shellfish [127, 128]. Table 1 provides examples of studies that report allochthonous pathogen occurrence in coastal waters. There are a limited number of studies that describe the fate and transport of allochthonous pathogens in the environment. These studies have generally highlighted the importance of pathogens associated with sediments [129] and show a positive correlation between the occurrence of pathogens and rainfall [130]. More research is clearly needed to understand the dynamics of pathogens once release to the environment.

Vibrio spp. represent the classic example of indigenous or autochthonous infectious microbes [144]. Other notable autochthonous infectious microbes include helminthes which are indigenous to fish populations which can be transmitted to humans via ingestion of undercooked fish [145] and amoeba which can enter the nasal cavity [118]. Common disease-causing Vibrio spp. include $V$. cholerae (toxigenic and nontoxigenic), V. mimicus, V. parahaemolyticus, V. vulnificus, and V. alginolyticus. V. cholerae and $V$. mimicus are closely related species, both of which cause gastroenteritis, $V$. parahaemolyticus causes gastroenteritis as well as wound infections, $V$. vulnificus can cause septis and wound infections, and $V$. alginolyticus can cause wound infections [119]. A number of studies have examined the environmental factors that control the occurrence of Vibrio spp. in coastal waters or within shellfish [146-149]. Common correlates to Vibrio concentrations include salinity and temperature; warmer temperatures typically correlate to higher Vibrio concentrations; salinity and Vibrio densities covary, but the direction depends on the organism. Vibrio have been shown in some cases to adsorb to zooplankton or phytoplankton and be associated with sediment [146, 150, 151]. Further information in V. cholerae, V. parahaemolyticus, and $V$. vulnificus can be found in excellent reviews on the organisms [152-154].

In order to protect human health and provide warnings for unsafe conditions, the presence of infectious microbes in coastal waters is evaluated through the use of "indicator" microbes. Indicator microbes are commensal inhabitants of the gastrointestinal tract of humans and are present in large numbers in fecal releases, especially releases from humans and warm blooded animals [155]. Indicator microbes are not necessarily pathogenic but are used as a surrogate for the presence of pathogenic microbes. For marine recreational waters, enterococci are the indicators recommended by the U.S. Environmental Protection Agency [156]. For freshwater recreational waters, both enterococci or E. coli are recommended [156]. The use of these microbes as indicators is supported by their correlation to measured, adverse, human health outcomes during epidemiology studies focused on illness during exposure to waters impacted by point sources of treated wastewater [157]. For shellfisheries in the US, fecal coliform are recommended to assess risk of exposure to pathogens through shellfish consumption [158].

Five basic dilemmas are associated with the use of indicator microbes to establish the safety of recreational waters. First, as enterococci and E. coli are natural inhabitants of the digestive tract of humans, the disease endpoint associated with these microbes is gastrointestinal disease. Although, gastrointestinal illness can be transmitted through water use [159], other types of illnesses can be transmitted during swimming including ear-, eye-, respiratory-, and skin-related diseases [160-162]. Second, studies have shown that in many 
TABLE 1: Examples of allothchonous human pathogens detected in coastal waters.

\begin{tabular}{|c|c|c|}
\hline Viruses & Concentration/Occurrence & Reference \\
\hline enteroviruses & $\begin{array}{l}\text { Present in } 9 \text { of } 72 \text { 1-liter samples using RT-PCR at Avalon Beach, CA*. Present in } 1 \text { of 18, 220-liter } \\
\text { samples using culture based methods for brackish water in St. Lucie River Estuary, FL. }\end{array}$ & {$[131,132]$} \\
\hline adenoviruses & Present in 15 of 30 250-liter samples using PCR at Silver Beach, MI* & {$[133]$} \\
\hline hepatitis A & 105 to 30,771 viral particles/liter using Q-RTPCR at Imperial Beach, CA* & {$[134]$} \\
\hline norovirus & 2 of 19 samples in 110-liters using RT-PCR at Key West sites (FL)* & [135] \\
\hline rotavirus (reovirus) & 2 of 19 sites with $2-5 \mathrm{MPN} / \mathrm{L}$ at Italian coastline & {$[136]$} \\
\hline \multicolumn{3}{|l|}{ Bacteria } \\
\hline Campylobacter & $\begin{array}{l}\text { Detected in } 25 \text { of } 192100-1000 \mathrm{~mL} \text { Spanish marine recreational water samples using culture based } \\
\text { methods }\end{array}$ & {$[137]$} \\
\hline Salmonella & $\begin{array}{l}\text { Detected in } 70 \%-100 \% \text { of samples from a lagoon in Brazil using culture-based methods, volume } \\
\text { assayed not reported }\end{array}$ & {$[138]$} \\
\hline Staphylococcus & $\begin{array}{l}60 \%-70 \% \text { of approx. } 100 \mathrm{~mL} \text { seawater samples from Doheny and Avalon Beach, CA using } \\
\text { culture-based methods. } 37 \% \text { of } 668,50 \mathrm{~mL} \text { seawater samples from Hobie Cat Beach, FL using } \\
\text { culture-based methods and confirmation by PCR }\end{array}$ & {$[139,140]$} \\
\hline Pathogenic E. coli & $\begin{array}{l}2 \text { of } 377 \text { E. coli isolates from North Carolina and Southern California coastal waters using combined } \\
\text { culture and PCR methods }\end{array}$ & {$[141]$} \\
\hline Shigella & $100 \%$ of algal mat samples from Lake Michigan near Burns Ditch by PCR & [142] \\
\hline Legionella sp. & Found in 35 of 72 samples from Lake Pontchartrain with 1 of 72 positive for L. pneumophila & {$[140]$} \\
\hline \multicolumn{3}{|l|}{ Protozoa } \\
\hline Cryptosporidium & $13.7 \pm 1.7$ oocysts/L on weekends at Chesapeake Bay beach, MD & {$[143]$} \\
\hline Giardia & $9.1 \pm 1.1$ cysts/L on weekends at Chesapeake Bay beach, MD & {$[143]$} \\
\hline
\end{tabular}

${ }^{*}$ Volumes reported do not account for the fact that a fraction of water sample was used during polymerase chain reaction (PCR), reverse-transcriptase- (RT-) PCR, or quantitative (Q) PCR.

cases indicator microbes do not track pathogenic microbes on a one-to-one basis $[163,164]$. Ortega et al. [131] have shown that sites subject to sporadic increases in indicator levels are also characterized by detectable levels of pathogens, although the time that the pathogens are detected do not necessarily coincide with the time that the indicator microbe levels exceed regulatory guideline levels. Abdelzaher et al. [165] found that indicators and pathogens are generally elevated during similar environmental conditions (low solar radiation, after rainfall, and during a particular tidal period), but this correspondence was not always consistent. The third dilemma associated with the use of indicator microbes is the time required to measure indicator bacteria using traditional culture methods. Traditional culture methods require an 18 to 24 hours incubation period before detection of the bacteria. As a result, contaminated beaches can remain open for a significant period of time before levels are known, thereby resulting in exposures to human populations. Conversely, as contamination tends to be highly variable [166], beaches can also be closed during times when they are safe. The fourth dilemma is that the use of E. coli and enterococci to assess risk was established using data from epidemiology studies conducted at beaches polluted by point sources of treated wastewater. At the present time, most point sources of pollution in the developed world are well regulated and controlled to minimize human health impacts. Nonpoint sources, including urban and agricultural runoff, wildlife feces, bather shedding, and other "environmental reservoirs" are leading contributors of E. coli and enterococci to coastal waters. There is some evidence that there is a human health risk upon exposure to indicators from nonpoint pollution sources [167], but there still exists a great deal of debate on the topic [132]. Finally, fecal indicator bacteria cannot be used to protect individuals from exposure to autochthonous pathogens, like Vibrio. Significant risk of Vibrio infections could be present when there are no fecal bacteria.

In the future, safety from infectious microbes in recreational waters and in seafood should consider multiple lines of evidence where indicator microbe measurements are supplemented with direct measures of a cluster of pathogenic targets that are relevant to the pollution sources and pathogens affecting the study area [168]. In addition, more work should be done to understand the ecology of allochthonous infectious microbes in the environment. Although these organisms are historically viewed as transient members of the microbial community of coastal waters, the coastal environment may serve as an important niche for these organisms to persist, exchange genetic material (for bacteria), and grow. Indeed, some researchers have found allochthonous pathogenic bacteria to be widespread in macroalgae of the Great Lakes [142]. Research is also needed to develop more rapid analyses methods for both indicators and pathogens [169], so that the time between measures and warnings can be reduced. Method detection limits also need to be improved if direct pathogen presence is to be considered for future monitoring purposes, as pathogens are typically present in very low numbers [169]. Currently, the procedures for measuring pathogens in environmental 
waters are time consuming, in part due to detection limit issues, and thus data on the environmental occurrence of infectious microbes is lacking.

Ideally, the public should be warned prior to adverse water quality events. Given the current limitations in microbial measurements with respect to labor and time, early warning systems will likely rely on models [170, 171] designed to predict health risks based upon readily measureable environmental parameters and impending environmental conditions. Such models will require direct measures of microbial water quality for calibration and verification purposes.

\section{Acknowledgments}

This paper was made possible through the Centers for Oceans and Human Health (COHH) program of the National Institute of Environmental Health Sciences (National Institutes of Health), and National Science Foundation that provided Grants nos. P50ES012740, OCE0432479, and OCE09-11000 to the University of Hawaii, Grants nos OCE0432368/0911373 and P50 ES12736 to the University of Miami, and Grants nos. OCE-0430724 and P50 ES012742 to the Woods Hole Oceanographic Institution.

\section{References}

[1] P. K. Bienfang, M. L. Parsons, R. R. Bidigare, E. A. Laws, and P. D. R. Moeller, "Ciguatera fish poisoning: a synopsis from ecology to toxicity," in Oceans and Human Health: Risks and Remedies from the Sea, P. J. Walsh, S. L. Smith, L. E. Fleming, H. Solo-Gabriele, and W. H. Gerwick, Eds., pp. 257-270, Elsevier, New York, NY, USA, 2008.

[2] R. W. Dickey, "Ciguatera toxins: chemistry, toxicology and detection," in Seafood and Freshwater Toxins: Pharmacology, Physiology, and Detection, L. M. Botana, Ed., pp. 479-500, CRC Press, Boca Raton, Fla, USA; Taylor \& Francis, London, UK, 2nd edition, 2008.

[3] R. W. Dickey and S. M. Plakas, "Ciguatera: a public health perspective," Toxicon, vol. 56, no. 2, pp. 123-136, 2010.

[4] P. Helfrich, "Fish poisoning in Hawaii," Hawaii Medical Journal, vol. 22, pp. 361-372, 1964.

[5] B. W. Halstead, Poisonous and Venomous Marine Animals of the World, vol. 2, U. S. Government Printing Office, 1967.

[6] J. P. Quod and J. Turquet, "Ciguatera in Reunion Island (SW Indian ocean): epidemiology and clinical patterns," Toxicon, vol. 34, no. 7, pp. 779-785, 1996.

[7] R. J. Lewis, “The changing face of ciguatera," Toxicon, vol. 39, no. 1, pp. 97-106, 2001.

[8] J. Pearn, "Neurology of ciguatera," Journal of Neurology, vol. 70, no. 1, pp. 4-8, 2001.

[9] P. Arena, B. Levin, L. E. Fleming, M. A. Friedman, and D. Blythe, "A pilot study of the cognitive and psychological correlates of chronic ciguatera poisoning," Harmful Algae, vol. 3, no. 1, pp. 51-60, 2004.

[10] N. D. Lewis, "Disease and development: coguatera fish poisoning," Social Science and Medicine, vol. 23, no. 10, pp. 983-993, 1986.

[11] W. R. Lange, "Ciguatera fish poisoning," American Family Physician, vol. 50, no. 3, pp. 579-584, 1994.
[12] L. E. Fleming, D. Katz, J. A. Bean, and R. Hammond, "Epidemiology of seafood poisoning," in Foodborne Disease Handbook, Y. H. Hui, D. Kitts, and P. Standfield, Eds., pp. 287-310, 2001.

[13] L. E. Fleming, D. G. Baden, J. A. Bean, R. Weisman, and D. G. Blythe, "Seafood toxin diseases: issues in epidemiology and community outreach," in Harmful Algae. Zunta de Galicia and Intergovernmental Oceanographic Commission of UNESCO, B. Reguera, J. Blanco, M. L. Fernandez, and T. Wyatt, Eds., pp. 245-248, 1998.

[14] J. Cameron, A. E. Flowers, and M. F. Capra, "Electrophysiological studies on ciguatera poisoning in man (Part II)," Journal of the Neurological Sciences, vol. 101, no. 1, pp. 9397, 1991.

[15] E. Benoit, P. Juzans, A. M. Legrand, and J. Molgo, "Reversal of Pacific ciguatoxin-1B effects on myelinated axons by agents used in ciguatera treatment," Cybium, vol. 24, no. 3, pp. 3340, 2000.

[16] M. A. Friedman, L. E. Fleming, M. Fernandez et al., "Ciguatera fish poisoning: treatment, prevention and management," Marine Drugs, vol. 6, no. 3, pp. 456-479, 2008.

[17] T. Yasumoto, I. Nakajima, R. Bagnis, and R. Adachi, "Finding of a dinoflagellate as a likely culprit of ciguatera," Bulletin of the Japanese Society for the Science of Fish, vol. 43, pp. 10211026, 1977.

[18] T. Yasumoto, A. Inoue, and R. Bagnis, "Ecological survey of a toxic dinoflagellate associated with ciguatera," in Toxic Dinoflagellate Blooms, D. L. Taylor and H. Seliger, Eds., pp. 221-224, Elsevier, New York, Ny, USA, 1979.

[19] T. Yasumoto, Y. Oshima, Y. Murakami, I. Nakajima, R. Bagnis, and Y. Fukuyo, "Toxicity of benthic dinoflagellates," Bulletin of the Japanese Society for the Science of Fish, vol. 46, pp. 327-331, 1980.

[20] R. Adachi and Y. Fukuyo, "The thecal structure of a marine toxic dinoflagellate Gambierdiscus toxicus gen. et sp. nov. collected in a ciguatera endemic area," Bulletin of the Japanese Society for the Science of Fish, vol. 45, pp. 67-71, 1979.

[21] M. A. Faust, "Observation of sand-dwelling toxic dinoflagellates (Dinophyceae) from widely differing sites, including two new species," Journal of Phycology, vol. 31, no. 6, pp. 9961003, 1995.

[22] M. J. Holmes, “Gambierdiscus yasumotoi sp. nov. (Dinophyceae), a toxic benthic dinoflagellate from Southeastern Asia," Journal of Phycology, vol. 34, no. 4, pp. 661-668, 1998.

[23] M. Chinain, M. A. Faust, and S. Pauillac, "Morphology and molecular analyses of three toxic species of Gambierdiscus (Dinophyceae): G. pacificus, sp. nov., G. australes, sp. nov., and G. polynesiensis, sp. nov," Journal of Phycology, vol. 35, no. 6, pp. 1282-1296, 1999.

[24] M. L. Richlen, S. L. Morton, P. H. Barber, and P. S. Lobel, "Phylogeography, morphological variation and taxonomy of the toxic dinoflagellate Gambierdiscus toxicus (Dinophyceae)," Harmful Algae, vol. 7, no. 5, pp. 614-629, 2008.

[25] R. W. Litaker, M. W. Vandersea, M. A. Faust et al., "Taxonomy of Gambierdiscus including four new species, Gambierdiscus caribaeus, Gambierdiscus carolinianus, Gambierdiscus carpenteri and Gambierdiscus ruetzleri (Gonyaulacales, Dinophyceae)," Phycologia, vol. 48, no. 5, pp. 344-390, 2009.

[26] K. A. Steidinger and D. G. Baden, "Toxic marine dinoflagellates," in Dinoflagellates, D. L. Spector, Ed., pp. 210-261, Academic Press, Orlando, Fla, USA, 1985. 
[27] H. Kite-Powell, "Public health and economic implications of oceans and human health research," in Proceedings of Oceans and Human Health Symposium of Workshop, Washington, DC, USA, April 2010.

[28] M.-L. Chateau-Degat, M. Chinain, N. Cerf, S. Gingras, B. Hubert, and É. Dewailly, "Seawater temperature, Gambierdiscus spp. variability and incidence of ciguatera poisoning in French Polynesia," Harmful Algae, vol. 4, no. 6, pp. 10531062, 2005.

[29] J. L. Perez-Arellano, O. P. Luzardo, A. Perez Brito et al., "First report of ciguatera fish poisoning in West-African coast: a public health concern in the Canary Islands (Spain)," Emerging Infectious Diseases, vol. 11, pp. 1981-1982, 2005.

[30] T. A. Villareal, S. Hanson, S. Qualia, E. L. E. Jester, H. R. Granade, and R. W. Dickey, "Petroleum production platforms as sites for the expansion of ciguatera in the northwestern Gulf of Mexico," Harmful Algae, vol. 6, no. 2, pp. 253-259, 2007.

[31] P. Bienfang, B. Oben, S. Defelice et al., "Ciguatera: the detection of neurotoxins in carnivorous reef fish from the coast of Cameroon, West Africa," African Journal of Marine Science, vol. 30, no. 3, pp. 533-540, 2008.

[32] P. A. Tester and K. A. Steidinger, "Gymnodinium breve red tide blooms: initiation, transport, and consequences of surface circulation," Limnology and Oceanography, vol. 42, no. 5, pp. 1039-1051, 1998.

[33] K. M. Kusek, G. Vargo, and K. Steidinger, "Gymnodinium breve in the field, in the lab, and in the newspapera scientific and journalistic analysis of Florida red tides," Contributions in Marine Science, vol. 34, pp. 1-229, 1999.

[34] C. C. Davis, "Gymnodinium brevis sp. nov., a cause of discolored water and animal mortality in the Gulf of Mexico," Botany Gaz, vol. 109, pp. 358-360, 1948.

[35] C. A. Heil, Vertical migration of ptychodiscus brevis (Davis) steidinger, M.S. thesis, University of South Florida, St. Petersburg, Fla, USA, 1986.

[36] D. Kamykowski, E. J. Milligan, and R. E. Reed, "Relationships between geotaxis/phototaxis and diei vertical migration in autotrophic dinoflagellates," Journal of Plankton Research, vol. 20, no. 9, pp. 1781-1796, 1998.

[37] K. A. Steidinger, G. A. Vargo, P. A. Tester, and C. R. Tomas, "Bloom dynamics and physiology of Gymnodinium breve with emphasis on the Gulf of Mexic," in Physiological Ecology of Harmful Algal Blooms, D. M. Anderson, A. D. Cembella, and G. M. Hallegraeff, Eds., pp. 133-153, Springer, Heidelberg, Germany, 1998.

[38] K. A. Steidinger, "Implications of dinoflagellate life cycles on initiation of Gymnodinium breve red tides," Environmental Letters, vol. 9, no. 2, pp. 129-139, 1975.

[39] M. Geesey and P. A. Tester, "Gymnodinium breve: ubiquitous in Gulf of Mexico waters," in Toxic Phytoplankton Blooms in the Sea, T. J. Smayda and Y. Shimizu, Eds., pp. 251-255, Elsevier, New York, NY, USA, 1993.

[40] L. E. Brand and A. Compton, "Long-term increase in Karenia brevis abundance along the Southwest Florida Coast," Harmful Algae, vol. 6, no. 2, pp. 232-252, 2007.

[41] P. A. Tester, R. P. Stumpf, F. M. Vukovich, P. K. Fowler, and J. T. Turner, "An expatriate red tide bloom: transport, distribution, and persistence," Limnology \& Oceanography, vol. 36, no. 5, pp. 1053-1061, 1991.

[42] M. J. Olascoaga, I. I. Rypina, M. G. Brown et al., "Persistent transport barrier on the West Florida Shelf," Geophysical Research Letters, vol. 33, no. 22, Article ID L22603, 2006.
[43] G. Gunter, R. H. Williams, C. C. Davis, and F. G. Walton Smith, "Catastrophic mass mortality of marine animals and coincident phytoplankton bloom on the west coast of Florida, November 1946-August 1947," Ecological Monographs, vol. 18, pp. 309-324, 1947.

[44] G. A. Rounsefell and W. R. Nelson, "Red-tide research summarized to 1964 including an annotated bibliography," U.S. Fish and Wildlife. Service Special Scientific ReportFisheries, no. 535, p. 85, 1966.

[45] L. K. Dixon and K. A. Steidinger, "Correlation of Karenia brevis presence in the eastern Gulf of Mexico and with rainfall and riverine flow," in Harmful Algae, K. A. Steidinger, J. H. Landsberg, C. R. Tomas, and G. A. Vargo, Eds., pp. 29-31, 2004.

[46] J. M. Lenes, B. P. Darrow, C. Cattrall et al., "Iron fertilization and the Trichodesmium response on the West Florida shelf," Limnology and Oceanography, vol. 46, no. 6, pp. 1261-1277, 2001.

[47] J. J. Walsh and K. A. Steidinger, "Saharan dust and Florida red tides: the cyanophyte connection," Journal of Geophysical Research C: Oceans, vol. 106, no. 6, pp. 11.597-11.612, 2001.

[48] J. J. Walsh, J. K. Jolliff, B. P. Darrow et al., "Red tides in the Gulf of Mexico: where, when, and why?" Journal of Geophysical Research C: Oceans, vol. 111, no. 11, Article ID C11003, 2006.

[49] C. Hu, F. E. Muller-Karger, and P. W. Swarzenski, "Hurricanes, submarine groundwater discharge, and Florida's red tides," Geophysical Research Letters, vol. 33, no. 11, Article ID L11601, 2006.

[50] G. A. Vargo, C. A. Heil, K. A. Fanning et al., "Nutrient availability in support of Karenia brevis blooms on the central West Florida Shelf: what keeps Karenia blooming?" Continental Shelf Research, vol. 28, no. 1, pp. 73-98, 2008.

[51] D. G. Baden, A. J. Bourdelais, H. Jacocks, S. Michelliza, and J. Naar, "Natural and derivative brevetoxins: historical background, multiplicity, and effects," Environmental Health Perspectives, vol. 113, no. 5, pp. 621-625, 2005.

[52] J. H. Landsberg, "The effects of harmful algal blooms on aquatic organisms," Reviews in Fisheries Science, vol. 10, no. 2, pp. 113-390, 2002.

[53] S. M. Watkins, A. Reich, L. E. Fleming, and R. Hammond, "Neurotoxic shellfish poisoning," Marine Drugs, vol. 6, no. 3, pp. 431-455, 2008.

[54] P. A. Tester, J. T. Turner, and D. Shea, "Vectorial transport of toxins from the dinoflagellate Gymnodinium breve through copepods to fish," Journal of Plankton Research, vol. 22, no. 1, pp. 47-61, 2000.

[55] L. J. Flewelling, J. P. Naar, J. P. Abbott et al., "Brevetoxicosis: red tides and marine mammal mortalities," Nature, vol. 435, no. 7043, pp. 755-756, 2005.

[56] J. P. Naar, L. J. Flewelling, A. Lenzi et al., "Brevetoxins, like ciguatoxins, are potent ichthyotoxic neurotoxins that accumulate in fish," Toxicon, vol. 50, no. 5, pp. 707-723, 2007.

[57] L. C. Backer, L. E. Fleming, A. Rowan et al., "Recreational exposure to aerosolized brevetoxins during Florida red tide events," Harmful Algae, vol. 2, no. 1, pp. 19-28, 2003.

[58] B. Kirkpatrick, L. E. Fleming, D. Squicciarini et al., "Literature review of Florida red tide: implications for human health effects," Harmful Algae, vol. 3, no. 2, pp. 99-115, 2004.

[59] L. E. Fleming, L. C. Backer, and D. G. Baden, "Overview of aerosolized Florida red tide toxins: exposures and effects," 
Environmental Health Perspectives, vol. 113, no. 5, pp. 618620, 2005.

[60] W. M. Abraham and D. G. Baden, "Aerosolized Florida red tide toxins and human health effects," Oceanography, vol. 19, pp. 107-109, 2006.

[61] B. Kirkpatrick, L. E. Fleming, L. C. Backer et al., "Environmental exposures to Florida red tides: effects on emergency room respiratory diagnoses admissions," Harmful Algae, vol. 5, no. 5, pp. 526-533, 2006.

[62] L. E. Fleming, B. Kirkpatrick, L. C. Backer et al., "Aerosolized red-tide toxins (brevetoxins) and asthma," Chest, vol. 131, no. 1, pp. 187-194, 2007.

[63] F. Alcock, "An assessment of Florida red tide," Tech. Rep. 1190, Mote Marine Laboratory, Sarasota, Fla, USA, 2007.

[64] M. Gantar and Z. Svirčev, "Microalgae and cyanobacteria: food for thought," Journal of Phycology, vol. 44, no. 2, pp. 260-268, 2008.

[65] P. B. Nunn and P. O'Brien, “The interaction of $\beta$ $\mathrm{N}$-methylamino-L-alanine with bicarbonate: an ${ }^{1} \mathrm{H}-\mathrm{NMR}$ study," FEBS Letters, vol. 251, no. 1-2, pp. 31-35, 1989.

[66] T. G. Myers and S. D. Nelson, "Neuroactive carbamate adducts of $\beta$-N-methylamino-L-alanine and ethylenediamine. Detection and quantitation under physiological conditions by ${ }^{13} \mathrm{C}$ NMR," Journal of Biological Chemistry, vol. 265, no. 18, pp. 10193-10195, 1990.

[67] A. Vega and E. A. Bell, " $\alpha$-amino- $\beta$-methylaminopropionic acid, a new amino acid from seeds of Cycas circinalis," Phytochemistry, vol. 6, no. 5, pp. 759-762, 1967.

[68] P. S. Spencer, P. B. Nunn, and J. Hugon, "Guam amyotrophic lateral sclerosis-Parkinsonism-dementia linked to a plant excitant neurotoxin," Science, vol. 237, no. 4814, pp. 517-522, 1987.

[69] U. Beckman Sundh, C. Andersson, J. Rosén, F. Fonnum, I. Knudsen, and S. Sippola, "Analysis, occurrence, and toxicity of $\beta$-methylaminoalanine (BMAA): a risk for the consumer?" TemaNord, vol. 516, p. 128, 2007.

[70] P. A. Cox, S. A. Banack, and S. J. Murch, "Biomagnification of cyanobacterial neurotoxins and neurodegenerative disease among the Chamorro people of Guam," Proceedings of the National Academy of Sciences of the United States of America, vol. 100, no. 23, pp. 13380-13383, 2003.

[71] P. A. Cox, S. A. Banack, S. J. Murch et al., "Diverse taxa of cyanobacteria produce $\beta-\mathrm{N}$-methylamino-L-alanine, a neurotoxic amino acid," Proceedings of the National Academy of Sciences of the United States of America, vol. 102, no. 14, pp. 5074-5078, 2005.

[72] R. Rippka, J. Deruelles, J. B. Waterbury, M. Herdman, and R. Y. Stanier, "Generic assignments, strain histories and properties of pure cultures of cyanobacteria," Journal of General Microbiology, vol. 111, no. 1, pp. 1-61, 1979.

[73] B. M. Kuehn, "Environmental neurotoxin may pose health threat," Journal of the American Medical Association, vol. 293, no. 20, pp. 2460-2462, 2005.

[74] P. G. Ince and G. A. Codd, "Return of the cycad hypothesisdoes the amyotrophic lateral sclerosis/parkinsonism dementia complex (ALS/PDC) of Guam have new implications for global health?" Neuropathology and Applied Neurobiology, vol. 31, no. 4, pp. 345-353, 2005.

[75] M. Esterhuizen and T. G. Downing, " $\beta-N$-methylaminol-alanine (BMAA) in novel South African cyanobacterial isolates," Ecotoxicology and Environmental Safety, vol. 71, no. 2, pp. 309-313, 2008.
[76] J. H. Weiss and D. W. Choi, " $\beta$-N-methylamino-L-alanine neurotoxicity: requirement for bicarbonate as a cofactor," Science, vol. 241, no. 4868, pp. 973-975, 1988.

[77] S. D. Rao, S. A. Banack, P. A. Cox, and J. H. Weiss, "BMAA selectively injures motor neurons via AMPA/kainate receptor activation," Experimental Neurology, vol. 201, no. 1, pp. 244252, 2006.

[78] D. Lobner, P. M. T. Piana, A. K. Salous, and R. W. Peoples, “ $\beta$ $\mathrm{N}$-methylamino-l-alanine enhances neurotoxicity through multiple mechanisms," Neurobiology of Disease, vol. 25, no. 2, pp. 360-366, 2007.

[79] R. R. Bidigare, S. J. Christensen, S. B. Wilde, and S. A. Banack, "Cyanobacteria and BMAA: possible linkage with avian vacuolar myelinopathy (AVM) in the south-eastern United States," Amyotrophic Lateral Sclerosis, vol. 10, supplement 2, pp. 71-73, 2009.

[80] E. J. Faassen, F. Gillissen, H. A. J. Zweers, and M. Lrling, "Determination of the neurotoxins BMAA ( $\beta$ $\mathrm{N}$-methylamino-L-alanine) and DAB $(\alpha$-, $\gamma$-diaminobutyric acid) by LC-MSMS in Dutch urban waters with cyanobacterial blooms," Amyotrophic Lateral Sclerosis, vol. 10, supplement 2, pp. 79-84, 2009.

[81] H. E. Johnson, S. R. King, S. A. Banack, C. Webster, W. J. Callanaupa, and P. A. Cox, "Cyanobacteria (Nostoc commune) used as a dietary item in the Peruvian highlands produce the neurotoxic amino acid BMAA," Journal of Ethnopharmacology, vol. 118, no. 1, pp. 159-165, 2008.

[82] J. S. Metcalf, S. A. Banack, J. Lindsay, L. F. Morrison, P. A. Cox, and G. A. Codd, "Co-occurrence of $\beta$-N-methylamino1-alanine, a neurotoxic amino acid with other cyanobacterial toxins in British waterbodies, 1990-2004," Environmental Microbiology, vol. 10, no. 3, pp. 702-708, 2008.

[83] T. A. Caller, J. W. Doolin, J. F. Haney et al., "A cluster of amyotrophic lateral sclerosis in New Hampshire: a possible role for toxic cyanobacteria blooms," Amyotrophic Lateral Sclerosis, vol. 10, supplement 2, pp. 101-108, 2009.

[84] P. A. Cox, R. Richer, J. S. Metcalf, S. A. Banack, G. A. Codd, and W. G. Bradley, "Cyanobacteria and BMAA exposure from desert dust: a possible link to sporadic ALS among Gulf War veterans," Amyotrophic Lateral Sclerosis, vol. 10, supplement 2, pp. 109-117, 2009.

[85] D. Craighead, J. S. Metcalf, S. A. Banack, L. Amgalan, H. V. Reynolds, and M. Batmunkh, "Presence of the neurotoxic amino acids $\beta$-N-methylamino-L-alanine (BMAA) and 2,4diamino-butyric acid (DAB) in shallow springs from the Gobi Desert," Amyotrophic Lateral Sclerosis, vol. 10, supplement 2, pp. 96-117, 2009.

[86] B. R. Roney, L. Renhui, S. A. Banack, S. Murch, R. Honegger, and P. A. Cox, "Consumption of fa cai Nostoc soup: a Potential for BMAA exposure from Nostoc cyanobacteria in China?" Amyotrophic Lateral Sclerosis, vol. 10, supplement 2, pp. 44-49, 2009.

[87] S. Jonasson, J. Eriksson, L. Berntzon et al., "Transfer of a cyanobacterial neurotoxin within a temperate aquatic ecosystem suggests pathways for human exposure," Proceedings of the National Academy of Sciences of the United States of America, vol. 107, no. 20, pp. 9252-9257, 2010.

[88] Z. Spácil, J. Eriksson, S. Jonasson, U. Rasmussen, L. L. Ilag, and B. Bergman, "Analytical protocol for identification of BMAA and DAB in biological samples," Analyst, vol. 135, no. 1, pp. 127-132, 2010.

[89] P. M. Scott, B. Niedzwiadek, D. F. K. Rawnben, and P.Y. Lau, "Liquid chromatographic determination of the cyanobacterial toxin $\beta$-N-methylamino-l-alanine in algae 
food supplements, freshwater fish, and bottled water," Journal of Food Protection, vol. 72, no. 8, pp. 1769-1773, 2009.

[90] T. Kubo, N. Kato, K. Hosoya, and K. Kaya, "Effective determination method for a cyanobacterial neurotoxin, $\beta$ N-methylamino-l-alanine," Toxicon, vol. 51, no. 7, pp. 1264 1268, 2008.

[91] J. Rosén and K.-E. Hellenäs, "Determination of the neurotoxin BMAA ( $\beta$-N-methylamino-L-alanine) in cycad seed and cyanobacteria by LC-MS/MS (liquid chromatography tandem mass spectrometry)," Analyst, vol. 133, no. 12, pp. 1785-1789, 2008.

[92] T. Krüger, B. Mönch, S. Oppenhäuser, and B. Luckas, "LCMS/MS determination of the isomeric neurotoxins BMAA ( $\beta$-N-methylamino-l-alanine) and DAB (2,4-diaminobutyric acid) in cyanobacteria and seeds of Cycas revoluta and Lathyrus latifolius," Toxicon, vol. 55, no. 2-3, pp. 547-557, 2010.

[93] C. Y. Kao, "Paralytic shellfish poisoning," in Algal Toxins in Seafood and Drinking Water, I. R. Falconer, Ed., pp. 75-86, Academic Press, London, UK, 1993.

[94] A. Prakash, J. Medcof, and A. Tennant, Paralytic Shellfish Poisoning in Eastern Canada, Fisheries Research Board of Canada, no. 177, Fisheries Research Board of Canada, Ottawa, Canada, 1971.

[95] D. M. Anderson, D. M. Kulis, Y.-Z. Qi, L. Zheng, S. Lu, and Y.-T. Lin, "Paralytic shellfish poisoning in Southern China," Toxicon, vol. 34, no. 5, pp. 579-590, 1996.

[96] M. E. E. Popkiss, D. A. Horstman, and D. Harpur, "Paralytic shellfish poisoning. A report of 17 cases in Cape Town," South African Medical Journal, vol. 55, no. 25, pp. 1017-1023, 1979.

[97] B. W. Halstead and E. Shantz, Paralytic Shellfish Poisoning, WHO Offset Publication, no. 79, World Health Organization, Geneva, Switzerland, 1984.

[98] D. M. Anderson, B. A. Keafer, D. J. McGillicuddy et al., "Initial observations of the 2005 Alexandrium fundyense bloom in southern New England: general patterns and mechanisms," Deep-Sea Research II, vol. 52, no. 19-21, pp. 2856-2876, 2005.

[99] D. J. McGillicuddy Jr., D. M. Anderson, D. R. Lynch, and D. W. Townsend, "Mechanisms regulating large-scale seasonal fluctuations in Alexandrium fundyense populations in the Gulf of Maine: results from a physical-biological model," Deep-Sea Research II, vol. 52, no. 19-21, pp. 2698-2714, 2005.

[100] L. C. Backer and D. J. McGillicuddy, "Harmful Algal Blooms: at the interface between coastal oceanography and human health," Oceanography, vol. 19, no. 2, pp. 94-106, 2006.

[101] D. M. Anderson, J. J. Sullivan, and B. Reguera, "Paralytic shellfish poisoning in northwest Spain: the toxicity of the dinoflagellate Gymnodinium catenatum," Toxicon, vol. 27, no. 6, pp. 665-674, 1989.

[102] D. G. Baden, "Marine food-borne dinoflagellate toxins," International Review of Cytology, vol. 82, pp. 99-150, 1983.

[103] D. M. Anderson and D. Wall, "Potential importance of benthic cysts of Gonyaulax tamarensis and G. excavata in initiating toxic dinoflagellate blooms," Journal of Phycology, vol. 14, no. 2, pp. 224-234, 1978.

[104] D. W. Townsend, N. R. Pettigrew, and A. C. Thomas, "Offshore blooms of the red tide dinoflagellate, Alexandrium sp., in the Gulf of Maine," Continental Shelf Research, vol. 21, no. 4, pp. 347-369, 2001.

[105] P. J. S. Franks and D. M. Anderson, "Toxic phytoplankton blooms in the southwestern Gulf of Maine: testing hypotheses of physical control using historical data," Marine Biology, vol. 112, no. 1, pp. 165-174, 1992.
[106] R. M. Luerssen, A. C. Thomas, and J. Hurst, "Relationships between satellite-measured thermal features and Alexandrium-imposed toxicity in the Gulf of Maine," DeepSea Research II, vol. 52, no. 19-21, pp. 2656-2673, 2005.

[107] C. A. Stock, D. J. McGillicuddy, A. R. Solow, and D. M. Anderson, "Evaluating hypotheses for the initiation and development of Alexandrium fundyense blooms in the western Gulf of Maine using a coupled physical-biological model," Deep-Sea Research II, vol. 52, no. 19-21, pp. 27152744, 2005.

[108] C. A. Stock, D. J. McGillicuddy Jr., D. M. Anderson, A. M. Solow, and R. P. Signell, "Blooms of the toxic dinoflagellate Alexandrium fundyense in the western Gulf of Maine in 1993 and 1994: a comparative modeling study," Continental Shelf Research, vol. 27, no. 19, pp. 2486-2512, 2007.

[109] R. He and D. J. McGillicuddy Jr., "Historic 2005 toxic bloom of Alexandrium fundyense in the west Gulf of Maine: 1. In situ observations of coastal hydrography and circulation," Journal of Geophysical Research C: Oceans, vol. 113, no. 7, Article ID C07039, 2008.

[110] R. He, D. J. McGillicuddy Jr., B. A. Keafer, and D. M. Anderson, "Historic 2005 toxic bloom of Alexandrium fundyense in the western Gulf of Maine: 2. Coupled biophysical numerical modeling," Journal of Geophysical Research C: Oceans, vol. 113, no. 7, Article ID C07040, 2008.

[111] J. Zaias, L. C. Backer, and L. E. Fleming, "Harmful algal blooms (HABs)," in Human-Animal Medicine: A Clinical Guide to Toxins, Zoonoses, and Other Shared Health Risks, P. Rabinowitz and L. Conti, Eds., pp. 91-104, Elsevier Science, New York, NY, USA, 2010.

[112] C. N. Haas, J. B. Rose, and C. P. Gerba, Quantitative Microbial Risk Assessment, John Wiley \& Sons, New York, NY, USA, 1999.

[113] L. C. Backer, J. K. Kish, H. M. Solo-Gabriele, and L. E. Fleming, "Naturally-occurring water pollutants," in Water and Sanitation Related Diseases and the Environment: Challenges, Interventions and Preventive Measures, J. Selendy, Ed., Horizon International, Yale University, 2010.

[114] H. Shuval, "Estimating the global burden of thalassogenic diseases: human infectious diseases caused by wastewater pollution of the marine environment," Journal of Water and Health, vol. 1, no. 2, pp. 53-64, 2003.

[115] National Research Defense Council (NRDC), "NRDC testing the waters," 2009, http://www.nrdc.org/water/oceans/ ttw/titinx.asp.

[116] U.S. Food and Drug Administration (U.S. FDA), "National Shellfish Registry," U.S. Food and Drug Administration and the Interstate Shellfish Sanitation Conference, The National Shellfish Register, 1995, http://seaserver.nos.noaa.gov/ projects/95register.

[117] S. Given, L. H. Pendleton, and A. B. Boehm, "Regional public health cost estimates of contaminated coastal waters: a case study of gastroenteritis at southern California beaches," Environmental Science and Technology, vol. 40, no. 16, pp. 4851-4858, 2006.

[118] J. S. Yoder, M. C. Hlavsa, G. F. Craun et al., "Surveillance for waterborne disease and outbreaks assoicated with recreational water use and other aquatic facility-associated health events-United States, 2005-2006," Morbidity and Mortality Weekly Report, vol. 58, no. 57/SS-9, pp. 1-38, 2008.

[119] M. Iwamoto, T. Ayers, B. E. Mahon, and D. L. Swerdlow, "Epidemiology of seafood-associated infections in the United States," Clinical Microbiology Reviews, vol. 23, no. 2, pp. 399411, 2010. 
[120] S. Nithiuthai, M. T. Anantaphruti, J. Waikagul, and A. Gajadhar, "Waterborne zoonotic helminthiases," Veterinary Parasitology, vol. 126, no. 1-2, pp. 167-193, 2004.

[121] C. D. Heaney, E. Sams, S. Wing et al., "Contact with beach sand among beachgoers and risk of illness," American Journal of Epidemiology, vol. 170, no. 2, pp. 164-172, 2009.

[122] I. Paquet-Durand, J. Hernández, G. Dolz, J. J. R. Zuñiga, T. Schnieder, and C. Epe, "Prevalence of Toxocara spp., Toxascaris leonina and ancylostomidae in public parks and beaches in different climate zones of Costa Rica," Acta Tropica, vol. 104, no. 1, pp. 30-37, 2007.

[123] C. Vogel, A. Rogerson, S. Schatz, H. Laubach, A. Tallman, and J. Fell, "Prevalence of yeasts in beach sand at three bathing beaches in South Florida," Water Research, vol. 41, no. 9, pp. 1915-1920, 2007.

[124] L. C. Backer, J. K. Kish, H. M. Solo-Gabriele, and L. E. Fleming, "Naturally-occurring water pollutants," in Water and Sanitation Related Diseases and the Environment: Challenges, Interventions and Preventive Measures, J. Selendy, Ed., John Wiley \& Sons, New York, NY, USA, 2010.

[125] D. W. Griffin, K. A. Donaldson, J. H. Paul, and J. B. Rose, "Pathogenic human viruses in coastal waters," Clinical Microbiology Reviews, vol. 16, no. 1, pp. 129-143, 2003.

[126] S. E. Henrickson, T. Wong, P. Allen, T. Ford, and P. R. Epstein, "Marine swimming-related illness: implications for monitoring and environmental policy," Environmental Health Perspectives, vol. 109, no. 7, pp. 645-650, 2001.

[127] R. Girones, S. Bofill-Mass, M. D. Furones, and C. Rodgers, "Foodborne infectious diseases and monitoring of marine food resources," in Oceans and Human Health: Risks and Remedies from the Sea, P. J. Walsh, S. L. Smith, L. E. Fleming, H. Solo-Gabriele, and W. H. Gerwick, Eds., pp. 359-380, Elsevier Science, New York, NY, USA, 2008.

[128] J. W. Santo Domingo and J. Hansel, "Waterborne diseases and microbial quality monitoring for recreational water bodies using regulatory methods," in Oceans and Human Health: Risks and Remedies from the Sea, P. J. Walsh, S. L. Smith, L. E. Fleming, H. Solo-Gabriele, and W. H. Gerwick, Eds., pp. 337-357, Elsevier Science, New York, NY, USA, 2008.

[129] L.-A. H. Krometis, G. W. Characklis, P. N. Drummey, and M. D. Sobsey, "Comparison of the presence and partitioning behavior of indicator organisms and Salmonella spp. in an urban watershed," Journal of Water and Health, vol. 8, no. 1, pp. 44-59, 2010.

[130] E. K. Lipp, R. Kurz, R. Vincent, C. Rodriguez-Palacios, S. R. Farrah, and J. B. Rose, "The effects of seasonal variability and weather on microbial fecal pollution and enteric pathogens in a subtropical estuary," Estuaries, vol. 24, no. 2, pp. 266-276, 2001.

[131] C. Ortega, H. M. Solo-Gabriele, A. Abdelzaher, M. Wright, Y. Deng, and L. M. Stark, "Correlations between microbial indicators, pathogens, and environmental factors in a subtropical Estuary," Marine Pollution Bulletin, vol. 58, no. 9, pp. 1374 1381, 2009.

[132] A. B. Boehm, N. J. Ashbolt, J. M. Colford Jr. et al., "A sea change ahead for recreational water quality criteria," Journal of Water and Health, vol. 7, no. 1, pp. 9-20, 2009.

[133] M. Wong, L. Kumar, T. M. Jenkins, I. Xagoraraki, M. S. Phanikumar, and J. B. Rose, "Evaluation of public health risks at recreational beaches in Lake Michigan via detection of enteric viruses and a human-specific bacteriological marker," Water Research, vol. 43, no. 4, pp. 1137-1149, 2009.
[134] R. M. Gersberg, M. A. Rose, R. Robles-Sikisaka, and A. K. Dhar, "Quantitative detection of hepatitis A virus and enteroviruses near the United States-Mexico border and correlation with levels of fecal indicator bacteria," Applied and Environmental Microbiology, vol. 72, no. 12, pp. 74387444, 2006.

[135] D. W. Griffin, C. J. Gibson III, E. K. Lipp, K. Riley, J. H. Paul III, and J. B. Rose, "Detection of viral pathogens by reverse transcriptase PCR and of microbial indicators by standard methods in the canals of the Florida Keys," Applied and Environmental Microbiology, vol. 65, no. 9, pp. 4118-4125, 1999.

[136] F. A. Aulicino, P. Orsini, M. Carere, and A. Mastrantonio, "Bacteriological and virological quality of seawater bathing areas along the Tyrrhenian coast," International Journal of Environmental Health Research, vol. 11, no. 1, pp. 5-11, 2001.

[137] J. L. Alonso and M. A. Alonso, "Presence of campylobacter in marine waters of Valencia, Spain," Water Research, vol. 27, no. 10, pp. 1559-1562, 1993.

[138] A. M. Gonzalez, R. Paranhos, and M. S. Lutterbach, "Relationships between fecal indicators and pathogenic microorganisms in a tropical lagoon in Rio de Janeiro, Brazil," Environmental Monitoring and Assessment, vol. 164, no. 1-4, pp. 207-219, 2010.

[139] K. D. Goodwin and M. Pobuda, "Performance of CHROMagar $^{T M}$ Staph aureus and CHROMagar ${ }^{T M}$ MRSA for detection of Staphylococcus aureus in seawater and beach sand-comparison of culture, agglutination, and molecular analyses," Water Research, vol. 43, no. 19, pp. 4802-4811, 2009.

[140] C. D. Sinigalliano, M. L. Gidley, T. Shibata et al., "Impacts of Hurricanes Katrina and Rita on the microbial landscape of the New Orleans area," Proceedings of the National Academy of Sciences of the United States of America, vol. 104, no. 21, pp. 9029-9034, 2007.

[141] A. L. Lang, Y.-L. Tsai, C. L. Mayer, K. C. Patton, and C. J. Palmer, "Multiplex PCR for detection of the heat-labile toxin gene and shiga-like toxin I and II genes in Escherichia coli isolated from natural waters," Applied and Environmental Microbiology, vol. 60, no. 9, pp. 3145-3149, 1994.

[142] S. Ishii, T. Yan, D. A. Shively, M. N. Byappanahalli, R. L. Whitman, and M. J. Sadowsky, "Cladophora (Chlorophyta) spp. harbor human bacterial pathogens in nearshore water of Lake Michigan," Applied and Environmental Microbiology, vol. 72, no. 7, pp. 4545-4553, 2006.

[143] T. K. Graczyk, D. Sunderland, L. Tamang, F. E. Lucy, and P. N. Breysse, "Bather density and levels of Cryptosporidium, Giardia, and pathogenic microsporidian spores in recreational bathing water," Parasitology Research, vol. 101, no. 6, pp. 1729-1731, 2007.

[144] D. P. Keymer, L. H. Lam, and A. B. Boehm, "Biogeographic patterns in genomic diversity among a large collection of vibrio cholerae isolates," Applied and Environmental Microbiology, vol. 75, no. 6, pp. 1658-1666, 2009.

[145] T. Scholz, H. H. Garcia, R. Kuchta, and B. Wicht, "Update on the human broad tapeworm (genus diphyllobothrium), including clinical relevance," Clinical Microbiology Reviews, vol. 22, no. 1, pp. 146-160, 2009.

[146] A. C. Wright, R. T. Hill, J. A. Johnson, M.-C. Roghman, R. R. Colwell, and J. G. Morris Jr., "Distribution of Vibrio vulnificus in the Chesapeake Bay," Applied and Environmental Microbiology, vol. 62, no. 2, pp. 717-724, 1996.

[147] K. R. O'Neill, S. H. Jones, and D. J. Grimes, "Seasonal incidence of Vibrio vulnificus in the Great Bay estuary of 
New Hampshire and Maine," Applied and Environmental Microbiology, vol. 58, no. 10, pp. 3257-3262, 1992.

[148] A. M. Zimmerman, A. DePaola, J. C. Bowers et al., "Variability of total and pathogenic vibrio parahaemolyticus densities in Northern Gulf of Mexico water and oysters," Applied and Environmental Microbiology, vol. 73, no. 23, pp. 7589-7596, 2007.

[149] R. R. Colwell, "Global climate and infectious disease: the cholera paradigm," Science, vol. 274, no. 5295, pp. 20252031, 1996.

[150] M. L. Tamplin, A. L. Gauzens, A. Huq, D. A. Sack, and R. R. Colwell, "Attachment of Vibrio cholerae serogroup O1 to zooplankton and phytoplankton of Bangladesh waters," Applied and Environmental Microbiology, vol. 56, no. 6, pp. 1977-1980, 1990.

[151] D. P. Keymer and A. B. Boehm, "Recombination shapes the structure of an environmental Vibrio cholerae population," submitted.

[152] S. W. Joseph, R. R. Colwell, and J. B. Kaper, "Vibrio parahaemolyticus and related halophilic Vibrios," Critical Reviews in Microbiology, vol. 10, no. 1, pp. 77-124, 1982.

[153] C. Pruzzo, A. Huq, R. R. Colwell, and G. Donelli, "Pathogenic Vibrio species in the marine and estuarine environment," in Oceans and Health: Pathogens in the Marine Environment, S. Belkin and R. Colwell, Eds., Springer Science, New York, NY, USA, 2006.

[154] J. D. Oliver, "Vibrio vulnificus," in Oceans and Health: Pathogens in the Marine Environment, S. Belkin and R. Colwell, Eds., Springer Science, New York, NY, USA, 2006.

[155] R. M. Maier, I. L. Pepper, and C. P. Gerba, Environmental Microbiology, Academic Press, New York, NY, USA, 2nd edition, 2008.

[156] U.S. Environmental Protection Agency, Ambient Water Quality Criteria for Bacteria, Office of Water Regulations and Standards, Washington, DC, USA, 1986, EPA 440/5-84-002.

[157] T. J. Wade, N. Pai, J. N. S. Eisenberg, and J. M. Colford Jr., "Do U.S. Environmental Protection Agency water quality guidelines for recreational waters prevent gastrointestinal illness? A systematic review and meta-analysis," Environmental Health Perspectives, vol. 111, no. 8, pp. 1102-1109, 2003.

[158] U.S. Food and Drug Administration, Guide for the Control of Molluscan Shellfish-Section IV, chapter 2, 2007, Growing Areas .01 Total Coliform Standards, http://www.issc.org/.

[159] C. P. Gerba, "Assessment of enteric pathogen shedding by bathers during recreational activity and its impact on water quality," Quantitative Microbiology, vol. 2, no. 1, pp. 55-68, 2000.

[160] N. Charoena and R. S. Fujioka, "Assessment of staphylococcus bacteria in Hawaii's marine recreational waters," Water Science and Technology, vol. 27, no. 3-4, pp. 283-289, 1993.

[161] J. M. Fleisher, L. E. Fleming, H. M. Solo-Gabriele et al., "The BEACHES study: health effects and exposures from nonpoint source microbial contaminants in subtropical recreational marine waters," International Journal of Epidemiology. In press.

[162] C. D. Sinigalliano, J. M. Fleisher, M. L. Gidley et al., "Traditional and molecular analyses for fecal indicator bacteria in non-point source subtropical recreational marine waters," Water Research, vol. 44, no. 13, pp. 3763-3772, 2010.

[163] R. T. Noble and J. A. Fuhrman, "Enteroviruses detected by reverse transcriptase polymerase chain reaction from the coastal waters of Santa Monica Bay, California: low correlation to bacterial indicator levels," Hydrobiologia, vol. 460, pp. 175-184, 2001.
[164] A. B. Boehm, K. M. Yamahara, D. C. Love, B. M. Peterson, K. Mcneill, and K. L. Nelson, "Covariation and photoinactivation of traditional and novel indicator organisms and human viruses at a sewage-impacted marine beach," Environmental Science and Technology, vol. 43, no. 21, pp. 8046-8052, 2009.

[165] A. M. Abdelzaher, M. E. Wright, C. Ortega et al., "Presence of pathogens and indicator microbes at a non-point source subtropical recreational marine beach," Applied and Environmental Microbiology, vol. 76, no. 3, pp. 724-732, 2010.

[166] A. B. Boehm, S. B. Grant, J. H. Kim et al., "Decadal and shorter period variability of surf zone water quality at Huntington Beach, California," Environmental Science and Technology, vol. 36, no. 18, pp. 3885-3892, 2002.

[167] R. W. Haile, J. S. Witte, M. Gold et al., "The health effects of swimming in ocean water contaminated by storm drain runoff," Epidemiology, vol. 10, no. 4, pp. 355-363, 1999.

[168] A. M. Abdelzaher, H. M. Solo-Gabriele, C. J. Palmer, and T. M. Scott, "Simultaneous concentration of enterococci and coliphage from marine waters using a dual layer filtration system," Journal of Environmental Quality, vol. 38, no. 6, pp. 2468-2473, 2009.

[169] K. D. Goodwin and R. W. Litaker, "Emerging technologies for monitoring recreational waters for bacteria and viruses," in Oceans and Human Health: Risks and Remedies from the Sea, P. J. Walsh, S. L. Smith, L. E. Fleming, H. Solo-Gabriele, and W. H. Gerwick, Eds., pp. 381-404, Elsevier Science, New York, NY, USA, 2008.

[170] M. B. Nevers and R. L. Whitman, "Nowcast modeling of Escherichia coli concentrations at multiple urban beaches of southern Lake Michigan," Water Research, vol. 39, no. 20, pp. 5250-5260, 2005.

[171] C. J. Palmer, J. A. Bonilla, T. D. Bonilla et al., "The future of microbial ocean water quality monitoring," in Oceans and Human Health: Risks and Remedies from the Sea, P. J. Walsh, S. L. Smith, L. E. Fleming, H. Solo-Gabriele, and W. H. Gerwick, Eds., pp. 405-421, Elsevier Science, New York, NY, USA, 2008. 

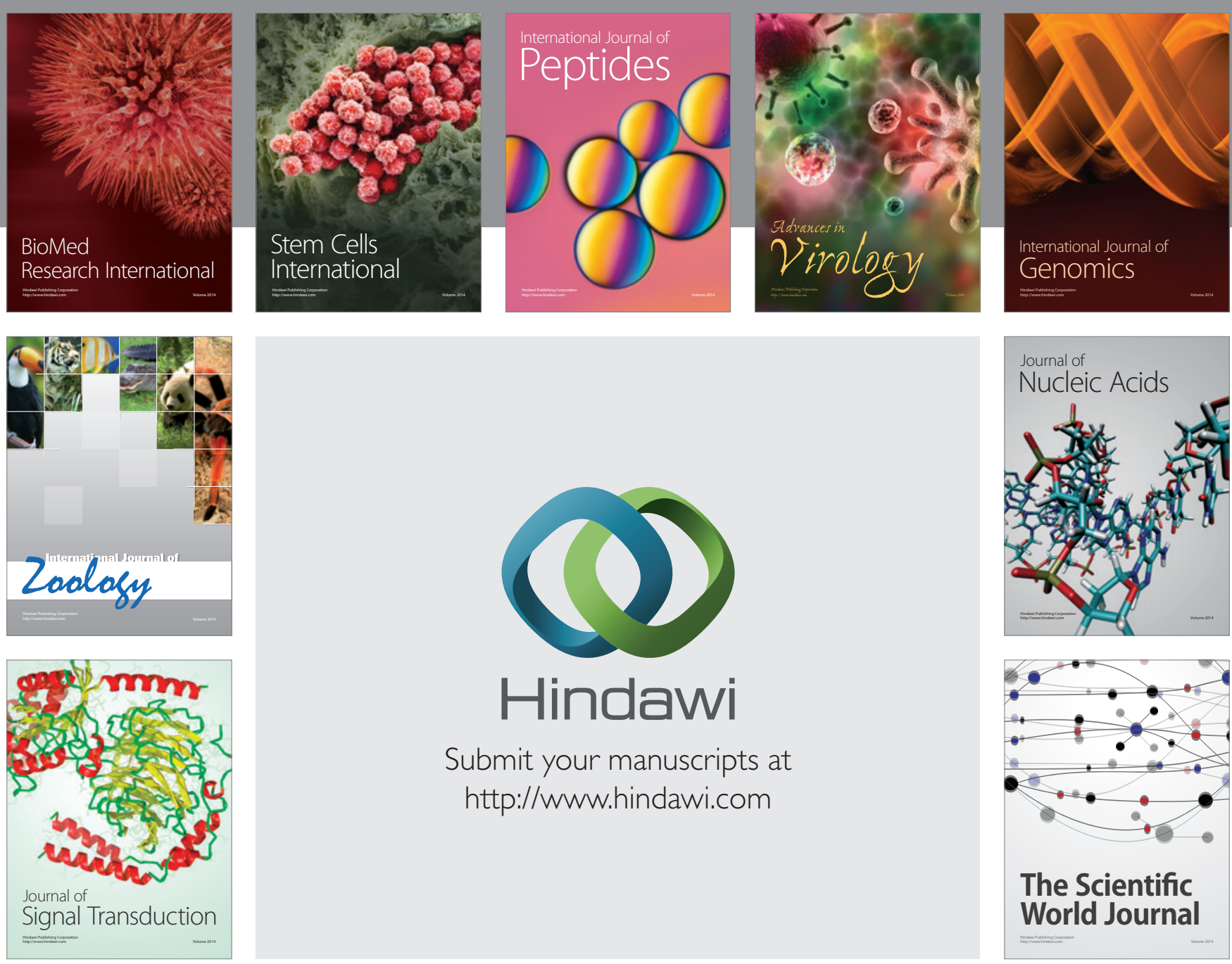

Submit your manuscripts at

http://www.hindawi.com
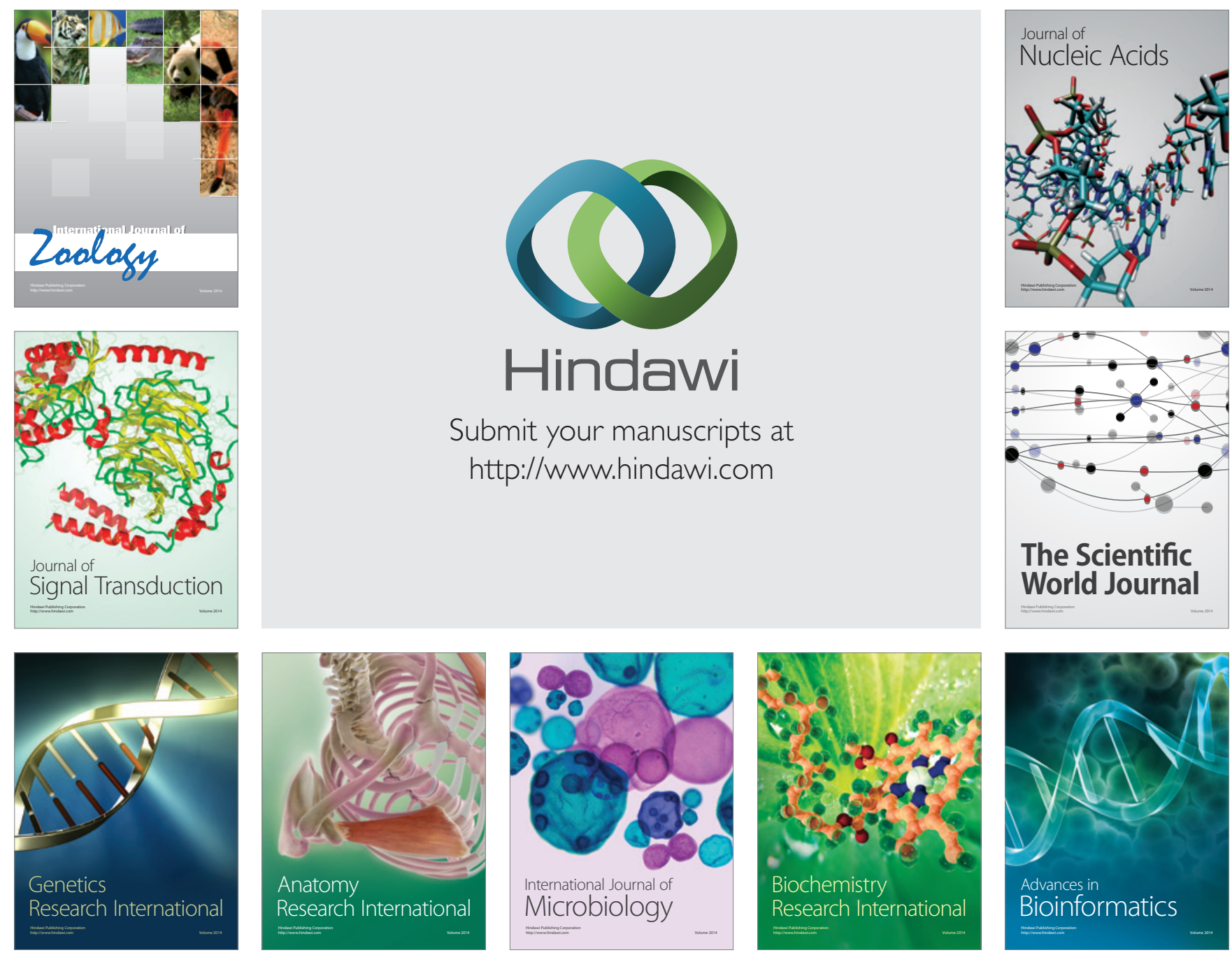

The Scientific World Journal
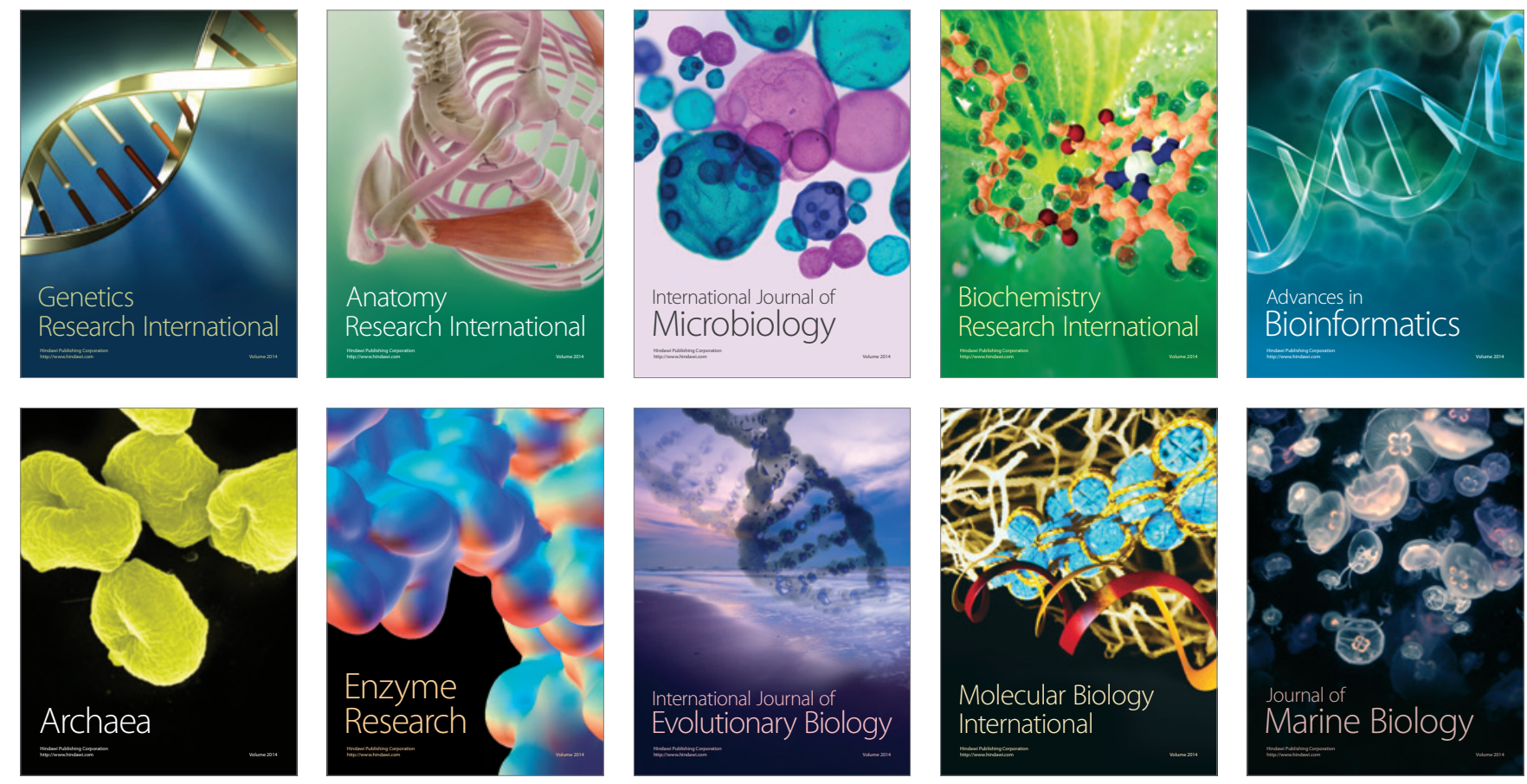